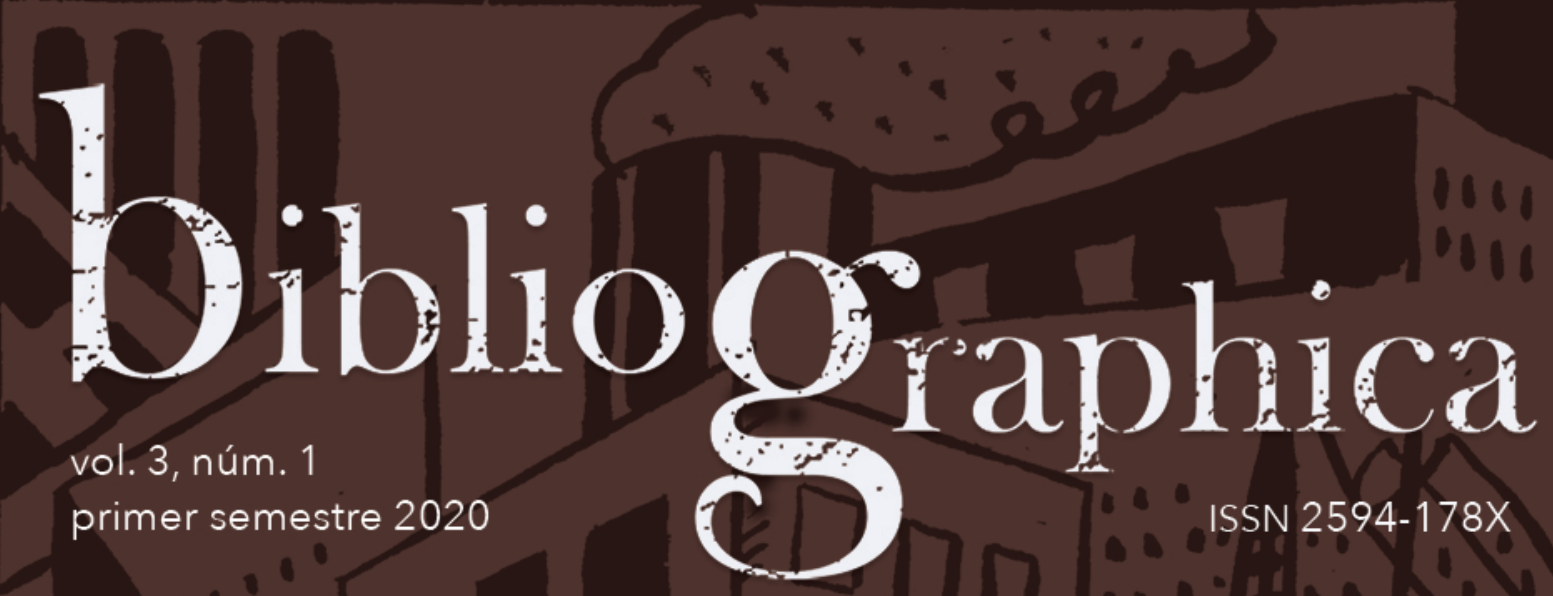




\title{
bibliog
}

\section{La crisis del campo editorial mexicano y el imaginario de sus trabajadores}

\author{
Mexican Publishing Field Grisis \\ and the Imaginary of its Guild
}

Gerardo Kloss Fernández del Castillo

gfkloss@gmail.com

Universidad Autónoma Metropolitana Xochimilco

División de Ciencias y Artes para el Diseño

Maestría en Diseño y Producción Editorial

Recepción: 02.10.2019 / Aceptación: 12.01.2020

DOI: https://doi.org/10.22201/iib.2594178xe.2020.1.65 
Resumen Reflexiones sobre los trabajadores del campo editorial mexicano y algunos de sus problemas, como las múltiples funciones del editor, los nuevos actores en el proceso, la precariedad laboral, la crisis actual y sus posibles proyecciones a futuro. La diversidad de las formas de producción y el consumo de los textos están en pleno reacomodo, debido a los novedosos soportes digitales, la fluidez y fragmentación de los contenidos y los nuevos modos de construir la percepción de la realidad en las redes sociales. Pero el imaginario de los trabajadores editoriales cultiva con cariño tantas idealizaciones que no les permite ver sus propias contradicciones y les resulta difícil abordar conscientemente las nuevas oportunidades, por lo cual prefieren verlas como amenazas a las que es preciso resistir.

Palabras clave

Abstract

Keywords
Industria editorial; libro; edición; lectura; estudios editoriales.

Thoughts about the professionals in the Mexican publishing field and some of their problems, such as the publisher's multiple functions, the new players in the process, the precarious work conditions, the current crisis and its possible projections into the future. The diversity in the forms of production and the consumption of texts are going through significant changes, due to the new digital formats, the fluidity and fragmentation of contents and the new ways in which the perception of reality is built in social networks. Nevertheless, the imaginary of the publishing professionals cherishes so many idealizations that this prevents them from becoming aware of their own contradictions and they are having a difficult time in consciously addressing new opportunities; therefore, many publishers rather see these changes as threats that must be resisted.

Publishing industry; book; publishing; reading; publishing studies. 
El mayor reto para un pensador es enunciar el problema de una forma que permita su solución.

Bertrand Russell

El sector editorial se parece al Club de la Pelea: nadie habla del sector editorial fuera del sector editorial.

Parece que a nadie de fuera del sector le interesa demasiado lo que sucede en el sector.

Aloma Rodríguez

\section{Introducción}

A los pobladores del mundo editorial mexicano les enorgullece pertenecer a una industria noble, producir algunos de los objetos más bellos y buenos, difundir la cultura, fomentar la educación y tener empleos agradables y creativos. Los trabajadores del campo editorial se han ido rodeando de hermosos sobrentendidos que, de tanto repetirse, se han vuelto transparentes: el libro es un hermoso objeto dotado de poder civilizatorio, leer nos vuelve mejores personas, debemos proteger la pureza del idioma... ¿Acaso alguien lo duda? Estas cosas ya son obvias: representan valores esenciales que no necesitan discutirse; pero como ya no se cuestionan en la vida diaria, palabras fundamentales como libro, lectura o editor van perdiendo poco a poco su contenido. Se vuelven poderosos tópicos poéticos para llenar emotivos discursos oficiales, pero pierden su poder explicativo para ayudarnos a esclarecer los pasados, los presentes y (lo que es peor) los futuros posibles del mundo editorial.

El historiador cultural Raymond Williams denomina "palabras clave" a este tipo de términos, ubicados en el núcleo de alguna creencia axiológica tan fundamental que se consideran autoevidentes al sentido común, y nadie (salvo algunos expertos) cree necesario debatirlos; se tienen por sobrentendidos, están altamente cargados de valores culturales, morales y éticos, y se usan con tanta frecuencia que adquieren significados diversos, alternativos y hasta contradictorios. Dice:

Las llamo palabras clave en dos sentidos conexos: son palabras significativas y vinculantes en ciertas actividades y en su interpretación; y son palabras significativas e indicativas en ciertas formas de pensamiento. Algunos usos enlazan 
algunas formas de ver la cultura y la sociedad [...] Algunos otros parecen abrir cuestiones y problemas de los cuales es preciso ser mucho más conscientes.

Cuando decimos que "no hablamos el mismo idioma" nos referimos a algo más general: que tenemos diferentes valores o tipos de valoración, o bien que somos conscientes, a veces de manera intangible, de diferentes formaciones y distribuciones de la energía y el interés.

Tomemos palabras como literatura, estético, representativo, empírico, inconsciente o liberal: estas y muchas otras palabras, que a mi juicio plantean problemas, parecerán en los círculos adecuados meras transparencias, y su uso correcto sólo una cuestión de educación. O bien clase, democracia, igualdad, evolución o materialismo: todos sabemos que debemos discutir sobre ellas, pero podemos atribuirles usos específicos en distintas sectas y considerarlas todas sectarias, menos a la nuestra. Puede decirse que el lenguaje depende de este tipo de confianza pero, especialmente en periodos de cambio, la necesaria confianza y la preocupación por la claridad pueden quebrarse rápidamente si no se enfrentan estos temas. ${ }^{1}$

\section{La crisis editorial en el imaginario}

El mundo editorial usa o, más bien, piensa a través de varias "palabras clave". Algunas -como texto, edición, libro, diseño, publicar, lectura o digital- tienen tal polisemia y se definen desde tantas perspectivas diferentes, pero a la vez son tan comunes y obvias, que es extremadamente difícil deconstruirlas, suscitan fuertes respuestas emocionales y movilizan ásperos debates. Por ejemplo, la lectura: todos dicen que leer es bueno, es un buen hábito, de personas buenas, que debe ser fomentado, pero no está así de claro qué significa leer, cómo se "fomenta" la lectura y cómo "evaluar" si la lectura se está "fomentando" con éxito.

Correctores, editores y diseñadores distinguen a simple vista algo mal editado, mal corregido o mal diseñado, pero siempre termina siendo polémico llegar a una definición sustantiva acerca de qué está bien, qué significa estar bien. Cada grupo y cada corriente, en cada disciplina, cultiva un discurso que considera sólido sobre cómo discernir lo que está mal y lo que está bien; pero las disputas entre esos mismos grupos, corrientes y disciplinas impiden cons-

1 Raymond Williams, Palabras clave. Un vocabulario de la cultura y la sociedad (Buenos Aires: Nueva Visión, 2003), 19-21. 
truir un consenso, transdisciplinario y ampliamente aceptado, que sea consistente y "enseñable" en todos los ramos de la producción editorial.

Ésta es una discusión importante (y no un puro academicismo) si, como decía Ludwig Wittgenstein, "los límites de mi lenguaje significan los límites de mi mundo". ${ }^{2}$ El libro, la revista y el periódico atraviesan una de las mayores crisis de su historia y su vulnerabilidad proviene, en parte, de su propia resistencia a repensarse. Si el editor se sigue pensando solamente como productor de objetos, y especialmente si sólo piensa en objetos poéticos y sensuales de papel, corre el riesgo de ocupar espacios cada vez más marginales en una sociedad donde el actual ecosistema editorial ya no fuera el único, y quizá ni siquiera el principal, y el valor agregado se trasladara de la venta de objetos hacia la gestión de contenidos.

La idealización del trabajo editorial no adquiere la misma forma en todos los géneros de la industria. Los editores literarios cultivan mitos quizá más elevados que los de libros de texto o de interés general, pero eso no implica que exista un sector editorial sin idealizaciones. Incluso la edición académica, técnica y científica, que no tiene obsesiones poéticas tan arraigadas y lleva años adaptándose a distintos sistemas digitales de gestión de contenidos, comparte algunos de los orgullos, arrogancias y obsesiones del oficio, como la actitud aprendida ante el error, y también algunas de sus negaciones, como negarse a saber cómo se distribuyen las revistas académicas, si tienen lectores o no, si circulan mejor en papel o en digital, si hay dispendio de recursos o si existen ejemplares rezagados en bodega. Mientras el material "salga", se alcance cierta bibliometría y fluya el financiamiento para los investigadores y sus proyectos, el trabajo es noble y bueno.

Durante muchos años se ha metaforizado la edición como una "cadena" que une a un autor ideal con un lector ideal a través de varios eslabones más o menos ideales, como dejaron establecido Robert Escarpit ${ }^{3}$ y Robert Darnton. ${ }^{4}$ Esta metáfora ha perdurado porque tiene gran poder descriptivo, pero también porque legitima la producción editorial, que hoy es todavía un poco artesanal, como la industria madre de otras cadenas productivas más modernas.

\footnotetext{
${ }^{2}$ Ludwig Wittgenstein, Tractatus logico-philosophicus (Barcelona: Alianza, 1981), 5-6.

${ }^{3}$ Robert Escarpit, Sociologie de la littérature (París: Presses Universitaires de France, 1958), 7, 83 .

${ }^{4}$ Robert Darnton, "Reading, Writing, and Publishing in Eighteenth Century. France: A Case Study in the Sociology of Literature", Daedalus 100(1) (1971): 216, y "What is the History of Books?", Daedalus 111(3) (1982): 66.
} 
Gutenberg era un empresario que se anticipó a la Revolución Industrial. Como decía McLuhan, el libro fue la primera mercancía producida en masa; en la imprenta de Gutenberg, en esa mercancía que se reproducía mecánicamente, nació el capitalismo moderno. Gutenberg fue precursor del fordismo, y seguramente había plusvalía y explotación en esa primera línea de producción. ${ }^{5}$

Sin embargo, hoy la idea de una "cadena" editorial podría estar describiendo cada vez menos lo que realmente hacemos, y ocultando nuevos sistemas más fluidos, caóticos y fragmentados de relaciones de explotación, detrás de la nostalgia por aquel bonito espacio laboral, estable, ordenado y entrañable, que producía objetos eternos y bellos con finalidades irrefutables, bajo la intención de las mentes más ilustradas y creativas.

Las buenas metáforas pueden ser poderosas herramientas conceptuales, u obstáculos para pensar. Por ejemplo, podríamos no estar viendo que la "cadena" está dejando de tener forma de cadena, que cada día hay más contenidos al alcance de los lectores y que en su creación, filtraje, producción, amplificación y uso participan muchos actores no tradicionales, como blogueros, video blogueros, redes sociales, buscadores, servicios de streaming, agregadores, autores auto publicados, agregadores de autores auto publicados y más, construyendo redes de relaciones que son todo menos lineales.

El "problema editorial" ya no pasa por la supuesta "muerte del libro" o "del papel", sino por algo más complejo de enunciar: el fin de la hegemonía exclusiva de las unidades discretas de información empaquetada en objetos y destinada a ser vendida de forma unitaria. Los relatos e información ya no se producen solamente dentro de cadenas de producción industrial centralizadas, con un único input y un output, ni están sólo a la venta por unidad, en envases cerrados, con fechas fijas de cierre y lanzamiento.

El papel no desaparecerá y el llamado Paréntesis de Gutenberg dista todavía mucho de ser un "perro muerto". Pero el papel (y las prácticas socialmente instituidas a su alrededor, nuestra cariñosa forma de entender la cultura escrita, la autoría, la edición, la corrección, el diseño, la imprenta, la librería, la lectura o la crítica literaria) ya no podrá seguir siendo un rasgo natural y obligatorio de todos los textos. La cultural editorial de los siglos XIX y XX sólo es y será uno más,

\footnotetext{
${ }^{5}$ Roger Chartier y Carlos A. Scolari, Cultura escrita y textos en red (Barcelona: Gedisa, 2019) y Chartier, "Gutenberg fue precursor del fordismo: Chartier", Babelia, El País Digital (7 de enero de 2019), acceso el 12 de febrero de 2020, https://elpais.com/cultura/2019/05/07/ babelia/1557222755_157917.html?id_externo_rsoc=TW_CC.
} 
entre los muchos estados y modos históricamente posibles de producir y consumir textos.

Es cierto que hoy vemos un incierto reacomodo en las formas de comunicación social y en los comportamientos de consumo cultural que invoca distopías como las de $1984^{\circ}$ o Un mundo feliz. ${ }^{7}$ Sin embargo, es un grosero lugar común atribuirle vagamente esta situación únicamente a "las nuevas tecnologías" en general, o asignarles cualidades morales a los objetos, como si el teléfono celular tuviera por sí mismo la culpa (o la expiación) de todos nuestros malestares sociales. La situación que vemos actualmente se originó en el año 2003, cuando Internet se convirtió en "Web 2.0", dejando de ser un canal principalmente unidireccional para volverse "social" o "colaborativo", y apareció el primer celular siempre conectado a la red, como una terminal individual portátil.

Las distopías de Orwell y Huxley fueron rebasadas, porque si bien sigue creciendo la concentración monopólica de poder y capitales (Penguin Random House, Grupo Planeta, Google, Amazon, Facebook), las nuevas formas de construir la percepción de realidad en las redes sociales no obedecen a la centralización sino, por el contrario, a una nueva multivocalidad descentralizada y omnidireccional, donde cada consumidor es un productor de contenidos y su sentido común impera sobre cualquier liderazgo de opinión.

La oralidad colaborativa, el rumor y el chisme nunca se fueron, pero tenían ciertas limitaciones para fijarse y reproducirse a través del filtro de la imprenta. Hoy las redes sociales permiten la fijación y reproducción de relatos colectivos con múltiples narradores que los cuentan, interpretan, modifican y difunden una y otra vez sin que exista autor, original, filtro, auctoritat verificable o "versión oficial". Las conspiranoias políticas pro y anti, los creepypastas y mitos adolescentes que asustan a padres y amigos, como Slenderman, Momo o la Ballena Azul, al igual que años atrás el chupacabras o los cuentos recabados por los hermanos Grimm, se forman colectivamente y son reproducidos a partir de una pequeña ficción local, para creer y pertenecer, construir identidad dentro de alguna comunidad y dar forma visible a emociones colectivas como el miedo o el enojo.

No todo es negativo. Se produce buena microficción en Twitter y complejos relatos transmediales en Facebook. Grupos musicales como Twenty One Pilots retan a sus seguidores a luchar contra la depresión y el suicidio a través de rompecabezas narrativos compuestos de música, videos en YouTube, mensajes

${ }^{6}$ George Orwell, Nineteen Eighty-Four (Londres: Secker and Warburg, 1949).

${ }^{7}$ Aldous Huxley, Brave New World (Londres: Chatto \& Windus, 1932). 
en redes sociales, fragmentos y pistas en forma de cartas, mapas o aparentes errores de código en su sitio web.

Esta fluidez fragmentaria de los contenidos (y de sus productores, que pueden ser cualquier persona, o ser anónimos, y provenir de cualquier parte) se refleja en los soportes, que van dejando de ser discretos, sólidos y cerrados. El propio modelo de comercialización ya no implica la compra de un objeto sólido (ni siquiera de un archivo digital), sino la renta de una licencia para el acceso temporal a un depósito donde los relatos y la información técnica, científica o periodística están disponibles en estado fluido. El negocio editorial se centra cada vez más en la capacidad para gestionar flujos de contenidos; se parece cada vez más a un rizoma o a una nube de partículas dispersas fluyendo en corrientes, y menos a una cadena lineal de producción, con eslabones estables y perfiles profesionales fijos, retratados como estampitas arquetípicas: "el editor", "el corrector", "el impresor", "el librero". ${ }^{8}$ Sin duda este problema es uno de los varios que están detrás de la precarización laboral de los trabajadores del sector editorial, que subjetivan e idealizan, pero difícilmente sistematizan las funciones laborales reales de cada perfil de puesto.

\section{¿Cuál es nuestro objeto de estudio?}

Pierre Bourdieu estudió el campo editorial francés comparando la estructura del capital económico y la antigüedad del capital simbólico de cada empresa, para analizar qué editoriales jugaban el rol de dominantes, ascendentes, antagonistas o disruptivas. ${ }^{9}$ En México ya se han hecho diversos estudios sobre las industrias culturales ${ }^{10}$ y particularmente sobre la industria editorial, ${ }^{11}$ pero se ha estudiado bastante menos el aspecto microsociológico de la interacción laboral cotidiana entre los individuos formados en el habitus y la illusio de campos distintos (por ejemplo, literatura, historia, comunicación, periodismo, diseño,

\footnotetext{
${ }^{8}$ Lisbeth Worsøe-Schmidt, "New Players in the Danish Book World. Challenges for the Sociology in Litterature", ponencia presentada en el Congreso de Estudios Editoriales By the Book 5, EuroPub, Florencia, Italia, 15 de junio de 2018.

9 Pierre Bourdieu, "Una revolución conservadora en la edición", en Intelectuales, política y poder (Buenos Aires: Eudeba, 2000), 223-267.

${ }_{10}$ Por ejemplo, entre los más recientes: Delia Crovi Druetta et al., Industrias culturales en México: reflexiones para actualizar el debate (México: Tintable, 2013).

${ }^{11}$ Véase Fernando Cruz Quintana, "Desarrollo histórico estructural de la industria librera mexicana en la era digital" (tesis de doctorado, UNAM, 2017).
} 
administración, derecho o mercadotecnia), al ingresar en el campo editorial (que, como tal, tiene su propio habitus, su propia illusio y su propio imaginario).

Son de nuestro interés las relaciones individuales en el espacio laboral y el contenido microsociológico de algunos roles arquetípicos de la cadena editorial, como autor, editor, corrector, diseñador o librero, en tanto que cada uno fue socializado con su propio habitus y su propia illusio, distinta del resto, pero todos comparten a la vez un legítimo interés por el libro, la industria editorial y la illusio propia de este campo. Sin embargo, estos arquetipos y sus prácticas institucionalizadas están en crisis, porque los trabajadores no saben decir exactamente qué hacen, no siempre hacen eso que dicen, ya no hacen lo que según la tradición deberían hacer y sus tareas ya no coinciden con sus perfiles laborales.

Por ejemplo, en español la prestigiosa palabra editor puede representar hasta 10 figuras laborales diferentes: la persona que toma la decisión de publicar, quien busca contenidos, negocia contratos, asesora autores; el director, dueño o socio capitalista de una editorial, el que organiza y dirige la producción, quien revisa, corrige, acomoda, copia, corta, pega, edita y le hace découpage a los textos, quien corrige estilo, revisa pruebas, organiza y prologa varias ponencias para hacer de ellas un libro, etcétera. Los editores son descritos a través de muchas etiquetas metafóricas: "audaces descubridores de talento", "enemigos de la innovación", "avaros negociantes", "vampiros que chupan la sangre de los poetas", 12 "fifís de la cultura", "prescriptores", "capitanes de barco", "directores de orquesta", "mártires por vocación", "todólogos incomprendidos", "valientes", "visionarios", "héroes anónimos", "negros", "esclavos", "mayordomos", "seres invisibles", "apostadores compulsivos", "perfeccionistas neuróticos, obsesivos y compulsivos" o "masoquistas con síndrome de Estocolmo", 13 pero es extremadamente difícil encontrar una definición precisa y ampliamente aceptada de lo que es un editor. Como también se usa la misma palabra para referirse a un dueño de empresa, a un director general, a un gerente, a un asistente o a un subordinado, y ya se trate de un capitalista, de un free lance o de un asalariado, resulta que muchos puestos aparentan de nombre ser igualitarios, pero tienen niveles extremadamente desiguales de poder, responsabilidad y remuneración.

El uso de palabras añejas, como oficio y gremio, parece dibujar en la imaginación de los trabajadores del sector editorial la idea de que pertenecen a un

\footnotetext{
12 Manuel Pimentel, Manual del editor (Córdoba: Berenice, 2007), 17.

${ }^{13}$ Gerardo Kloss Fernández del Castillo, "Discursos, imaginarios y conflictos en la inserción del diseño en el campo de la edición" (tesis de doctorado, UAEM, 2016), 357.
} 
grupo solidario y romántico de nobles artesanos, una especie de mutualidad armónica de sabios, iniciados en los arcanos de un altísimo apostolado cultural. Esta dulce imagen los hace retroceder en la imaginación, llenos de orgullo, hasta una mítica Edad de Oro del libro, la imprenta y las letras, que el imaginario parece situar entre el Renacimiento y la llustración, pero que sólo existió como la conocemos durante los siglos XIX y XX. Esta idealización nos impide pensar a la industria editorial como algo quizá mucho más complejo, terrible, materialista y violento. Mi propuesta es que la pensemos como un campo social, cuyos agentes compiten sin piedad por los capitales económicos, culturales, sociales y simbólicos.

Estos campos fueron descritos por el sociólogo francés Pierre Bourdieu como espacios sociales estructurados por la existencia de distintas posiciones. Un campo social se define (entre otras cosas) porque tiene intereses específicos y ciertos objetos en juego (enjeux) que sólo son percibidos por los integrantes del mismo campo, es decir, personas educadas y socializadas dentro del sistema de creencias y valores que organiza ese campo. ${ }^{14}$ Para que un campo social funcione tiene que haber gente dispuesta a jugar el juego y dotada de un habitus: personas que conozcan y respeten sus leyes y hagan parte de su propia vida la importancia de los objetos que se juegan, hasta el grado de llevarlos a una subjetivación que se expresa a través de un conjunto de representaciones sociales, es decir, un imaginario.

Los campos sólo son observables a través de sus efectos. La "estructura" de un campo no es sinónimo de un organigrama formal o de un sistema de relaciones fijas e institucionalizadas; solamente es un estado temporal de la relación de fuerzas entre los agentes e instituciones implicados en la lucha; es decir, es un estado de la distribución de los capitales (económicos, culturales, sociales y simbólicos) acumulados durante las luchas anteriores (y que, claro, orientan las estrategias de las luchas siguientes).

Las posiciones son relativas entre sí e independientes de quienes las ocupan, aunque las creencias y acciones de las personas sí resultan determinadas por las posiciones que ocupan (o se preparan para ocupar) dentro del juego, por ejemplo, para jugar como agentes dominantes, protagónicos, antagónicos, conservadores, disruptivos, etcétera.

\footnotetext{
${ }^{14}$ Pierre Bourdieu, "Algunas propiedades de los campos", en Sociología y cultura (México: Conaculta, 1990), 135-141.
} 
Las reglas del juego no suelen ser evidentes e incluso resultan invisibles para quienes están fuera del campo y carecen del habitus: están impasibles, con ataraxia, frente a las preocupaciones que parecen tan graves vistas desde adentro del campo. Por el contrario, quienes sí han sido socializados creyendo que el juego tiene sentido, que editar libros y revistas es necesario, que las reglas de la edición bien hecha son importantes y sus apuestas valen la pena, y que han pagado un precio por ser admitidos dentro del campo, han subjetivado el habitus al grado de poseer un legítimo interés en el juego, que Bourdieu denomina illusio. Este interés subjetivo los hace creer que son libres al elegir sus creencias y decisiones, porque no solamente están convencidos de que son las correctas, de que el libro es bueno, sino que para ellos son las únicas posibles y verdaderas; no están conscientes de hasta qué punto estas creencias y decisiones son aprendidas, provienen de su socialización, se representan en su imaginario y resultan irrelevantes para otros sujetos fuera del campo.

Como la estructura de cualquier campo es sólo un estado de la relación de fuerzas, es cambiante: siempre está en juego y es el principio de cualquier estrategia destinada a conservarla o transformarla. Las luchas que ocurren dentro de un campo tienen por objetivo conservar la estructura durante el mayor tiempo posible, o subvertirla cambiando la distribución de los capitales. La lucha puede ser por el monopolio de algún tipo de violencia simbólica, o para apoderarse de algún capital específico o de alguna forma particular de autoridad sobre los demás que otros integrantes del campo reconozcan como deseable y característica de ese campo.

Hablar de capital "específico" implica que sólo vale en relación con las reglas de ese campo y dentro de sus límites. Los capitales más apreciados en la illusio de un campo (tener más dinero, ser más hábil que los demás para meter goles o, en el caso del campo editorial, haber leído, editado, corregido, diseñado, impreso o vendido más libros) no necesariamente despiertan el mismo interés en otros campos.

Estos capitales pueden ser de cuatro tipos: capital económico (dinero, tierras, fábricas, negocios, bienes o derechos patrimoniales, de donde emana el poder del empresario para hacer valer sus decisiones en la empresa de su propiedad), capital cultural (conocimientos, habilidades y saberes, de donde procede el poder de los expertos para imponer su criterios en las materias de su especialidad, mientras enfrenten con éxito a quien ponga su erudición a prueba), capital social (relaciones sociales, familia, redes de amigos, cuates, compadres, palancas, afecto, confianza y disposición para colaborar, en una industria 
donde los mejores negocios, contratos y ofertas de trabajo se consiguen de boca a boca) y capital simbólico (fama, prestigio, honor y reconocimiento, de donde deriva el poder de un autor, de un crítico o de un sello editorial para imponerse a los demás).

Los conceptos capital simbólico, social y cultural permiten entender la economía cultural, la edición, el arte, los museos, la literatura y otros fenómenos que implican intercambios culturales y simbólicos, no únicamente económicos, y que el capital económico no explica por sí solo. Los cuatro tipos de capital pueden acumularse e intercambiarse, y todos corresponden al tiempo de trabajo que se requiere para su obtención. La relación entre el capital económico y el tiempo de trabajo requerido para acumularlo ya había sido descrita por Carlos Marx, pero la innovación de Bourdieu es que también considera "capital" el tiempo de trabajo invertido en acumular conocimientos, habilidades, relaciones, apoyo y reconocimiento, y que la suma de todos estos capitales permite competir por cierta autoridad específica dentro de un campo.

El capital cultural, en particular, tiene tres estados: incorporado, objetivado e institucionalizado. El capital cultural incorporado lo llevamos en el cuerpo y resulta del trabajo invertido en acumular conocimientos, saberes, habilidades o práctica, y en ser capaz de hacer o saber cosas que no cualquiera hace o sabe, como escribir, editar libros, corregir textos, dibujar, bailar, meter goles, dar buenas clases o resolver ecuaciones. La inmensa mayoría de los trabajadores del campo editorial ostentan un rico capital cultural, que es requisito para ingresar en el propio campo, aunque hay disputas cotidianas por el valor de los capitales culturales provenientes de disciplinas y habitus distintos, como literatura, periodismo, comunicación, diseño, ciencias naturales, derecho o salud.

El capital cultural objetivado es el trabajo invertido en acumular ciertos objetos especiales que denotan algún tipo de saber, porque no cualquiera reconoce su valor y es capaz de usarlos correctamente. Esta categoría incluye manuscritos, obras de arte, jarrones o muebles, así como muchos otros objetos que poseen un efecto "educativo" por el solo hecho de existir y denotan que su dueño es "alguien que sabe", por ejemplo el mejor instrumental médico (que solamente un buen médico gasta en adquirir), la mejor cámara (que sólo un fotógrafo realmente serio sabe usar), el mejor automóvil, la mejor computadora, mejores relojes, plumas, libros, etcétera. Una repisa llena de libros denota cierto tipo de saber por el solo hecho de existir y posee, junto con su valor económico y de uso, la importante función de visibilizar el capital cultural. 
El capital cultural institucionalizado es el trabajo que invierte una persona en acumular el reconocimiento formal de su saber por parte de las instituciones: premios, diplomas, certificados, cargos, títulos académicos, homenajes, etcéte$\mathrm{ra}^{15}$ aunque poseer este capital no necesariamente representa uno incorporado o viceversa: Quod natura non dat, Salmantica non præstat.

Quienes ingresan al campo editorial por primera vez deben pagar una cuota de ingreso, de la cual depende que sean seleccionados o cooptados como miembros: pasar pruebas y demostrar su adhesión; reconocer el valor del juego, la importancia de los objetos en juego y las figuras de las autoridades dominantes del campo; leer sus textos, aprenderse sus mitos y leyendas, reunir ciertos conocimientos, habilidades, libros, herramientas, ropas y distintivos, asistir a ciertos eventos y demostrar su respeto práctico de las reglas.

En todos los campos hay pequeñas revoluciones parciales, que en realidad no cuestionan las bases mismas del juego. En un estado determinado de fuerzas, quienes dominan el campo tienden a usar estrategias de conservación. En los campos culturales esto implica defender la ortodoxia y el canon. En cambio los "fuereños", los jóvenes y los recién llegados tienden a elegir estrategias subversivas, heréticas y heterodoxas, críticas contra la doxa del discurso dominante, a veces disfrazadas de "retorno a los orígenes" o "renovación" del verdadero espíritu del juego, contra la "degradación" causada por las "desviaciones" o el "anquilosamiento" de los agentes dominantes.

Los ataques contra la doxa sacan de su silencio a los agentes dominantes y los obligan a producir discursos defensivos, legitimadores de la ortodoxia, para tratar de restaurar la adhesión silenciosa de los demás agentes del campo. Un factor que protege el juego de una revolución total, capaz de destruirlo, es precisamente que la enorme inversión en tiempo, dinero y esfuerzo, los ritos de paso y las pruebas de lealtad requeridas para entrar en el campo hace impensable para los jóvenes la destrucción pura y simple del juego. El cuestionamiento contra los agentes dominantes sólo es para hacerlos a un lado y reemplazarlos por otros agentes más jóvenes, pero no para dejar de jugar.

Por más ferozmente que luchen entre sí, todos los agentes implicados en un mismo campo tienen una larga serie de intereses fundamentales en común, unidos a la existencia misma del campo. Si los integrantes de un mismo campo son rivales, es justamente porque desean lo mismo y, por eso, debajo de

\footnotetext{
${ }^{15}$ Pierre Bourdieu, "Los tres estados del capital cultural", en Las estrategias de la reproducción social (Buenos Aires: Siglo XXI, 2011), 213-220.
} 
sus antagonismos hay una complicidad objetiva. Todos los que participan en la lucha contribuyen a la reproducción del juego, fortaleciendo la creencia en sus reglas y en el valor de los objetos en juego.

Una evidencia de la constitución de un campo es la relación visible con la obra de otros agentes, pasados o contemporáneos, y la aparición de especialistas en conservar sus relatos, vidas y obras. Hay un "efecto de campo" cuando es imposible comprender un texto, imagen u obra y su valor sin conocer la historia de su campo de producción, saberse sus leyendas y reconocer por nombre, trayectoria de vida, obras y anécdotas a sus autoridades. Ya ha corrido mucha tinta en torno del intento por definir lo que es un editor y el papel que le corresponde jugar en la economía cultural, pero muchos estudios sociológicos sobre los editores en México analizan el campo editorial como si los editores fueran las empresas editoriales en sí mismas, invisibilizando la dinámica social que se presenta entre sus trabajadores. Por eso, si para Bourdieu "ser filósofo es dominar lo que hay que dominar de la historia de la filosofía para saber comportarse como filósofo ante un campo filosófico",16 para los fines de estudiar qué piensan acerca de sí mismos los trabajadores del campo editorial podríamos decir que ser editor es saber todo lo que hay que saber de la edición para poder comportarse como editor delante de los demás editores.

Elegir este enfoque teórico para analizar la forma en que los trabajadores de la industria editorial conceptualizan su propia labor, su lugar en la "cadena" de producción, la importancia de lo que hacen y los conflictos entre ellos, conlleva apropiarse de términos como habitus, leyes del juego, estado del juego, objetos en juego (enjeux) e intereses específicos del campo, relación de fuerzas entre los agentes o las instituciones, capitales económicos, sociales, simbólicos y culturales, lucha por la autoridad, conservación y subversión de la estructura, y discursos defensivos o legitimadores.

\section{El estudio}

Desde 2012, entre otras tareas, he entrevistado a diversos personajes de la cadena editorial, con una metodología cualitativa y enfocada en escuchar y analizar relatos, más que en conseguir la objetividad o la representatividad cuantitativa. La versión final del estudio consistió en 24 entrevistas realizadas semiestructuradas en la XXVIII Feria Internacional del Libro de Guadalajara, en-

$\overline{16}$ Bourdieu, "Algunas propiedades...", 135-141. 
tre el 30 de noviembre y el 3 de diciembre de 2014; en algunos casos, las entrevistas fueron pactadas en la FIL y se realizaron pocos días después. ${ }^{17}$ La muestra no fue planeada para ser estadísticamente representativa por su tamaño, sino para comparar los relatos con los que le dan contenido a sus labores, relaciones y conflictos los distintos agentes: al menos cuatro autores, cuatro editores, cuatro correctores, cuatro diseñadores, cuatro libreros y cuatro ejemplos de otros profesionales como ilustradores, responsables de producción, gestores culturales o promotores de lectura.

Juan Luis Álvarez Gayou define entrevista como "una conversación que tiene una estructura y un propósito", para "entender el mundo desde la perspectiva del entrevistado y desmenuzar el significado de sus experiencias"; ${ }^{18}$ semiestructurada implica que hay "una secuencia de temas y algunas preguntas sugeridas", pero "el diseño específico de la investigación indicará si esta guía se tiene que seguir puntualmente o no durante la entrevista". La pregunta ¿a qué se dedica usted? es para conocer si los roles protagónicos de la cadena son los arquetípicos (autor, editor, corrector, diseñador, etcétera), y reiterar con ¿qué actividades concretas realiza? es para verbalizar si el contenido concreto de esos roles arquetípicos realmente es similar en todos los casos. Resultó extremadamente revelador, por ejemplo, que los informantes dijeran: "eso es muy obvio, todos sabemos lo que el prestigioso Rol X significa", pero que cada entrevistado le haya dado contenidos diferentes a $X$.

¿Cuál es la importancia de lo que hace? y ¿qué pasaría si no se hiciera? pretenden sacar a la luz los discursos de legitimación de los distintos agentes. ¿Qué es para usted un editor? busca ampliar las descripciones y que broten desde el imaginario de los editores, pero también de los demás agentes. Preguntar ¿cómo se relaciona usted con los otros agentes de la edición? y ¿cuál de esas relaciones es la más gratificante y cuál es la más conflictiva? pretende ayudarnos a comprender las reglas, objetos del juego (enjeux), disputas, alianzas y rivalidades de cada agente con los demás dentro del campo. Una pregunta aparentemente anecdótica, ¿cómo aprendió a hacer lo que hace?, pretende mostrar la manera en que opera el proceso de socialización secundaria dentro del propio campo. ${ }^{19}$

\footnotetext{
${ }^{17}$ Kloss, "Discursos, imaginarios y conflictos...", 339.

18 Juan Luis Álvarez Gayou, Cómo hacer investigación cualitativa. Fundamentos y metodología (México: Paidós, 2009), 109-110.

19 Peter Berger y Thomas Luckmann, La construcción social de la realidad (Buenos Aires: Amorrortu, 2003), 172-183.
} 
De las casi 200 cuartillas de transcripciones surge la mayoría de las observaciones plasmadas en este artículo. Antes que nada, constatamos que las trayectorias de los informantes son híbridas: todos han estudiado y ejercido varias prácticas distintas, y se enorgullecen de aportarle al campo algún capital cultural de la carrera que originalmente estudiaron o abandonaron. La estructura del campo no es rígida y permite una gran movilidad. Las 24 entrevistas incluyen: una autora de libros para niños; una autora de divulgación que además promueve la lectura; un creador literario que ha sido corrector, editor y director de publicaciones de una universidad; una editora que también ha escrito libros para su propia editorial; la editora de una revista que produce, asimismo, libros; un editor que ha sido traductor, fotógrafo, gestor cultural y librero; tres directores generales de editoriales comerciales de libros de texto; tres editores que también han sido correctores, uno que ha hecho creación literaria y dos que han sido funcionarios públicos; tres diseñadores gráficos que dirigen editoriales; dos diseñadores gráficos que dirigen editoriales y además uno es ilustrador y el otro librero; dos correctores académicos; dos responsables de producción; un grabador e ilustrador que ha sido diseñador y editor de imágenes; un ilustrador que ha sido diseñador, músico y gestor cultural; y dos libreros, uno que es promotor cultural y el otro funcionario universitario. Dos tercios de ellos son invitados regularmente a dar clases en diferentes niveles, pero ninguno de los entrevistados depende de la docencia como su principal fuente de ingresos.

Al preguntarles qué es para ellos un editor, una sorprendente mayoría de las respuestas siguen siendo metáforas. ${ }^{20}$ Recordemos que Aristóteles definió la metáfora como "dar a un objeto un nombre que pertenece a algún otro", 21 es decir, hablar de una cosa usando los términos de otra, ya sea para hacer poesía o analogía; esta última intentando hablar de la cosa sin usar sus propios términos, muchas veces porque no se quiere o no se puede hacer. Michael Bhaskar parafrasea la obra de Göran Therborn: ¿Qué hace la clase dominante cuando domina?, ${ }^{22}$ al preguntarse qué hacen los editores cuando editan, y esa es una buena forma de evadir la vacuidad de las palabras clave. Al principio, al preguntarles qué hacían, los entrevistados se autodefinieron rápidamente dentro de alguno de los arquetipos aceptados (yo soy editor, diseñador, autor, corrector, librero, promotor cultural, ilustrador), hasta que insistimos en que enu-

\footnotetext{
20 Kloss, "Discursos, imaginarios y conflictos...", 354.

${ }^{21}$ Aristóteles, Poética (Madrid: Gredos, 1974), 204-206.

${ }^{22}$ Göran Therborn, ¿Cómo domina la clase dominante? (Madrid: Siglo XXI España, 1979).
} 
meraran sus tareas reales: ¿qué cosas concretas hace usted? ¿Qué problemas resuelve usted realmente? ¿Qué contenido concreto le otorga usted a ese término arquetípico con que se define a sí mismo? Al pedirles que describieran las funciones concretas que realizan día a día, fue posible sacar a los entrevistados de los casilleros arquetípicos y observar cómo describen actividades sumamente diversas, a pesar de tener los mismos perfiles nominales.

Como sugiere Worsøe-Schmidt, ${ }^{23}$ el progresivo desdibujamiento de la "cadena" (y su conversión en "rizoma", "hélice", "enjambre", "nube" o cualquier otra nueva metáfora) ya no puede analizarse mirando los puestos y oficios tradicionalmente instituidos en la propia cadena ni antropomorfizando los perfiles arquetípicos (como si ellos mismos fueran retratos inmóviles de héroes o figuras del juego de lotería: "El Autor", "El Editor", "El Corrector"), sino yendo directamente a las tareas y a las funciones.

Una vez liberadas de los arquetipos, las funciones reales adquieren mucho más detalle: generar ideas, crear contenido, financiar la creación, escribir, reescribir; seleccionar lo que se publica, sugerir cambios, decir que sí, decir que no; coordinar un equipo, financiar la publicación, vender proyectos y hacer marketing previo; corregir y editar textos, hacer cambios sustantivos y accidentales; ilustrar; producir imágenes; manufacturar, diseñar, formar tipografía, capturar, programar, imprimir, encuadernar, controlar calidad; hacer marketing a posteriori; distribuir, diseñar el display; hacer publicidad y ventas, atender puntos de venta; vender en persona, a escuelas, a bibliotecas, por correo, por Internet; definir políticas de descuentos y promociones; dar servicios al lector; evaluar la publicación, ponerla en medios, reseñar, criticar, consagrar, canonizar; recuperar información; archivar; promover el pass along; reutilizar, reciclar, desechar. ${ }^{24}$

De las muchas decisiones que implica una edición, la "decisión de publicar" es la que definió históricamente el núcleo de lo que era y hacía un editor o, como se dice en el resto del mundo, un publisher. Todo el proceso editorial -incluyendo el editing o découpage de los textos, el diseño (en sentido tradicional) y la impresión, fabricación, distribución y venta de los libros- consiste en tareas que pueden contratarse con terceros. Pero el poder de decisión para apostar capital económico y simbólico a unos contenidos y no a otros, fue durante muchos siglos el alma verdadera del negocio editorial.

\footnotetext{
${ }^{23}$ Worsøe-Schmidt, "New Players...".

${ }^{24}$ Adaptado de Worsøe-Schmidt y Johan Svedjedal, The Literary Web: Literature and Publishing in the Age of Digital Production (Estocolmo: Kungliga Biblioteket, 2000), 130.
} 
El Romanticismo nos legó la encantadora imagen de que la "cadena editorial" era echada a andar por la inspiración creativa del autor, quien, una vez plasmada su obra en un manuscrito, tenía que llevarla ante un editor. Eventualmente, después de que el autor había cumplido el rito iniciático de llamar a mil puertas, alguno de esos extraños seres era lo bastante culto, comprensivo y generoso para apostar por la promesa escondida en el joven rostro del novelista aficionado o en el sufrimiento del poeta maldito.

Hace más de un siglo que los autores desconocidos no triunfan llamando a la puerta de las editoriales. Quien les abre no es un editor en jefe, audaz descubridor de talentos, sino un policía, que le da el manuscrito a un recepcionista y éste tal vez a algún asistente editorial. La mayoría de los contenidos no solicitados, o unsols, son rechazados sin que nadie los lea, o se almacenan en espera de que algún becario tenga tiempo de revisarlos.

Desde el siglo XV la decisión de publicar (o no) ha dependido casi por completo de una rigurosa ecuación matemática que logra (o no logra) empatar demanda, tiraje, costo de producción, precio de venta al público y margen de utilidad. Igual todavía insistimos en pensar al editor desde la metáfora del olfato, que en la práctica no es sino una mezcla de experiencia, cultura, conocimiento del campo y sus reglas, marketing, planeación, asesoría, evaluación, dictaminación, revisión técnica, trabajo en equipo, autoridad, discurso legitimador, capital económico, cultural, social y simbólico.

Un complejo y variado ecosistema formado por críticos, agentes y gurúes literarios, árbitros, lectores, comités, ferias, jurados, premios, editores, directores de colección, funcionarios educativos y asesores pedagógicos se ha encargado, mediante una diversidad de mecanismos, de filtrar y "sugerir" dónde conviene más arriesgar el capital económico y simbólico de las editoriales para reproducir ciertos relatos (y no otros) o cierta información (y no otra). Este ecosistema organiza el poder de decidir, en cada campo social, en cada disciplina académica y en cada género literario, en una sociedad determinada, de qué temas pueden hablar los libros (o no), qué relatos pueden ser contados (o no), qué es "literatura" o "ciencia". En algunos casos arquetípicos, grandes figuras han utilizado partes de este sistema para orientar el gusto del público, desarrollando y fortaleciendo con éxito ciertas expresiones literarias. ${ }^{25}$ Pero esto no ocurre de manera generalizada.

${ }^{25}$ Freja I. Cervantes Becerril, "Colecciones y formación de gustos literarios en México", Andamios: Revista de Investigacion Social 6, núm. 12 (diciembre de 2009). 
Volviendo a Bourdieu, las piezas de estos dispositivos institucionales ${ }^{26}$ sirven como "bancos de capital simbólico" que legitiman la decisión de invertir en un contenido, pero no en otro. Asimismo, cada vez es más frecuente publicar obras por encargo, ediciones del editor y comandas de la mercadotecnia, muchas veces asociadas con los ritmos y tiempos de otros productos, como los útiles escolares, el cine o la televisión.

Los libros, revistas y periódicos son bienes culturales. Tienen un impacto concreto en las políticas educativas, la construcción de comunidades de cultura y de opinión pública, la formación de los ciudadanos y muchos otros aspectos de la vida social, incluyendo la reproducción y crítica de las reglas que rigen la convivencia civil y la acumulación del poder y del dinero. Por eso los editores siguen acariciando el ideal casi platónico de que no producen cualesquiera mercancías ordinarias y de que deberían estar por encima de las fuerzas que gobiernan el mercado.

No obstante, cuando se trata de que los lectores se lleven la mano del corazón a los bolsillos, la edición es una industria como cualquier otra y sus productos tienden a comportarse en el mercado como mercancías comunes y corrientes, lo que los obliga a competir contra cientos de bienes de consumo y opciones de entretenimiento. Este es un debate clásico que ya abordaron la UNESCO, ${ }^{27}$ Alison Baverstock,${ }^{28}$ Gill Davies, ${ }^{29}$ Carmen Barvo, ${ }^{30}$ Leonard Schatzkin, ${ }^{31}$ Manuel Pimentel, ${ }^{32}$ Michael Bhaskar ${ }^{33}$ y muchos otros.

Esta dualidad de la labor editorial es muy difícil de entender para quienes creen en la contradicción insalvable entre la cultura y el dinero. Así lo dictan nuestras antiguas creencias: "el arte y la literatura no deben prostituirse por dinero"; y su polo opuesto, la visión economicista de que "invertir en cultura es tirar el dinero a la basura".

\footnotetext{
${ }^{26}$ Bourdieu, "Una revolución conservadora...", 223-227.

27 UNESCO, Profession: éditeur (Montreal: HMH Hurtubise, 1993), 5.

${ }^{28}$ Allison Baverstock, Are Books Different? Marketing in the Book Trade (Londres: Kogan Page / BHTC, 1993), 13-29.

${ }^{29}$ Gill Davies, Book Commissioning and Acquisition (Londres: Blueprint, 1995), 12-57.

${ }^{30}$ Carmen Barvo, Manual de edición (Bogotá: Cerlalc, 1996), 28-36.

${ }^{31}$ Leonard Schatzkin, Cómo seleccionar títulos rentables. Herramientas estadísticas para la venta de libros (México: FCE, 2005), 1-5.

32 Pimentel, Manual del editor, 79, 141-180.

${ }_{33}$ Michael Bhaskar, La máquina de contenido. Hacia una teoría de la edición desde la imprenta hasta la red digital (México: FCE, 2014).
} 
Desde una postura romántica, el éxito de una editorial debería medirse por la calidad de sus aportaciones culturales y no por los beneficios económicos que genera. Esto es muy noble, pero un tanto engañoso si, como empresa, se sobrevive apenas al borde de la quiebra o se depende (directa o indirectamente) del Estado. Desde la visión opuesta, medir el éxito de una empresa editorial sólo a través de sus estados financieros también es engañoso, al menos para entender la complejidad del fenómeno editorial, ya que, además de intercambiar capital cultural (literario, científico, artístico) por capital económico, una edición implica cuantiosas transacciones de capital simbólico. El negocio editorial, y las industrias culturales en un sentido más amplio, han exigido siempre dominar el difícil arte de convertir capital simbólico y cultural (literario, artístico, científico) en capital económico, y reproducir el ciclo convirtiéndolo nuevamente en más capital cultural y simbólico.

Al publicar literatura, por ejemplo, no sólo se arriesga dinero. Se apuesta a la gran inversión de capital simbólico que el autor y su contenido reciben de un sello editorial prestigioso, y al probable retorno de capital simbólico que el sello editorial recibirá por haber incorporado en su catálogo un contenido o a un autor que serán bien valorados por la crítica y el público. No vale lo mismo publicar en una editorial desconocida que bajo el capital simbólico de Gredos, Cátedra o Alfaguara, quienes parecen sentar a su autor al lado de los grandes autores: "donde ponemos este sello, ponemos autores muy buenos". Este capital simbólico se acumula reclutando autores prestigiosos, pero es transferible a autores jóvenes que prometen ser capaces de ofrecer un retorno de las dos inversiones que se arriesgan al editarlos: la que se hace en dinero y la que se hace en prestigio.

Desde la pura visión económica, las editoriales universitarias y gubernamentales son grandes ejemplos de fracaso, al operar a fondo perdido y "tirar el dinero a la basura", malgastando un capital económico que no tendrá retorno. Pero el fenómeno es mucho más complejo: ese dinero, más que perderse es invertido exitosamente en acumular más capital simbólico, social y cultural para la institución..., o para quienes la encabezan.

Otro territorio mitológico es el de la lectura. Leer no es una sola práctica, normada y bien determinada, ni lo es hoy en día ni lo ha sido a lo largo de la historia. La lectura se practica de muchas formas y con muy variados propósitos. Nadie lee sólo "por hábito", porque "leer es bueno", porque "nos vuelve mejores personas" o porque "es un derecho", como dicen los mitos consagrados. Todos los lectores leen por motivos muy concretos: para satisfacer una necesidad, una obligación o un deseo, por ejemplo. 
La cadena editorial idealmente sólo se consuma "del autor al lector", pero al preguntarles a nuestros informantes con qué otros agentes de la cadena tienen su relación más conflictiva o gratificante, el trato con los lectores casi no apareció como significativo. ${ }^{34}$ Estos trabajadores editoriales declaran que piensan mucho en los textos y en los objetos que los portan, pero escasamente mencionan a las personas que los usan. Por suerte, la única excepción consistente fueron los libreros.

El sentido común asume que "los libros son para leer" como "las sillas son para sentarse", pero estas dos afirmaciones sólo abarcan una pequeña parte del problema. La gente no llega a una mueblería pidiendo "una silla para sentarse": eso se da por descontado. La gente se sienta en una silla a hacer algo en el marco de alguna interacción social, empleando cierto tipo específico de silla que es, denota que es-, sirve- y se usa- para un propósito como "sentarse a comer", "a estudiar", "a rezar", "a escribir", "a leer", "a legislar", "a gobernar", "a que me corten el pelo", "a que me curen los dientes". La silla solamente es un medio para hacer, en posición sedente, todas esas otras cosas que la gente realmente quiere hacer.

Todas las sillas son para sentarse, sí, pero el dentista no quiere un sillón de peluquero y el peluquero no quiere una silla de dentista. Una silla presidencial es más grande y cómoda que una silla gerencial, y ésta es más que una silla secretarial, porque el tamaño y la comodidad también denotan una escala jerárquica de poder. A veces el valor de signo de una silla y de lo que puede hacerse con ella es tan específico que ya no se llama "silla", sino "banco", "equipal", "pupitre", "cátedra", "sillón", "curul", "escaño" o "trono": es muy claro que jugar a las sillas no significa lo mismo que juego de tronos.

La economía, ergonomía, ética, lógica y estética de los materiales que constituyen una silla no están solamente determinados por la silla misma ni por el simple acto de sentarse, sino por los propósitos e interacciones que las personas pretenden desarrollar mientras están sentadas en la silla. Si la sociedad o el Estado creen que la posición sedente es buena -independientemente del propósito- y forma mejores personas, lo que se necesita no es promulgar una Ley Federal de Fomento de La Silla y El Sentarse ni regalar sillas de manera indiscriminada, sino investigar formas de favorecer las distintas interacciones sociales en las que resulta deseable usar diferentes tipos de sillas.

${ }^{34}$ Kloss, "Discursos, imaginarios y conflictos...", 374. 
Algo similar sucede con los libros, revistas y periódicos: en principio se hacen para ser leídos, pero el problema sociológico estriba en que la gente los lee para conseguir sus propios fines, que pueden ser estéticos o de prestigio, pero también pueden ser de muchos otros tipos y determinan mucho más su economía, lógica, estética y ética que el simple acto de leer sólo "porque leer es bueno". La primera y más grande treta semántica de los editores es hablar de "El Libro" en singular, como si todos los libros fueran iguales, o porque, como abstraen los tianguistas: "nos venimos dedicando a lo que viene siendo el zapato". Gabriel Zaid sostiene que un libro puede ser:

obra personal, objeto de arte, producto industrial, incunable, documento oficial, instructivo práctico, juguete para niños, reportaje de hechos recientes, serie de poemas, enciclopedia, colección de fascículos, recetario de cocina, material gratuito para la enseñanza primaria, medalla o placa conmemorativa que reparten las instituciones para su mayor gloria, medio kilo de basura, tres horas de lectura divertida, revelación que cambia la conciencia del mundo y de sí mismo, monumento a la cultura nacional, libro de texto, edición crítica o popular de un clásico, transcripción de archivos, base de datos estadísticos, novela que conduce al patíbulo. ${ }^{35}$

\section{La enseñanza}

La enseñanza de la edición y del diseño editorial no suele tomar en cuenta el aspecto antropológico esencial de cualquier comportamiento de consumo, incluyendo el cultural: no mirar al objeto, sino mirar la necesidad, lo que la gente realmente hace con los objetos. El lugar común dicta que "el libro es bueno" porque "leer nos vuelve mejores personas", sin cuestionar por qué, cómo o para qué, y eso es todo. Lo más que solemos hacer para averiguar qué quieren los lectores es marketing, pero solamente en algunos ramos, sólo como marketing operativo (no estratégico) y únicamente para mejorar las ventas, no para indagar y satisfacer necesidades humanas. En palabras del periodista y editor británico Holbrook Jackson, "el propósito de la lectura no es conseguir que se vendan más libros, sino que los lectores disfruten más de la vida". ${ }^{6}$

${ }^{35}$ Gabriel Zaid, "Por una ley del libro", en Crítica del mundo cultural (México: El Colegio Nacional, 1999), 108-115.

${ }^{36}$ Holbrook Jackson, The Reading of Books (Nueva York: Scribner's, 1947), 15. La traducción es mía. 
Estos huecos conceptuales son más agudos en América Latina y en los países en desarrollo, donde la edición y el diseño editorial se siguen enseñando como una especie de labor artesanal, de modo que la profesionalización (formar agentes de cambio, que analicen el ayer y hoy para innovación del mañana) raras veces se distingue de la simple capacitación para el trabajo (que suele dirigirse únicamente a optimizar la reproducción rutinaria de lo mismo que se ha hecho siempre).

En México solamente han existido tres programas académicos con título universitario en edición; los tres han sido a nivel de maestría y uno de ellos tiene casi 24 años cerrado. No existe ninguna licenciatura en edición y, aunque hay una docena de escuelas de literatura, comunicación y diseño gráfico que ofrecen opciones terminales de licenciatura dedicadas a la edición, hacer libros todavía es visto más como una desviación del canon académico que como una salida natural para estas profesiones. Parece que el egresado de letras sólo está realmente instruido para trabajar con textos literarios, el de comunicación con el contenido informativo y el de diseño con las formas, las imágenes y los materiales, pero la universidad no dedica mucho esfuerzo a enseñar el funcionamiento completo de la cadena.

En otros países no es así. En Europa, Norteamérica y el Extremo Oriente hay un campo académico, no muy grande ni muy antiguo, pero sí en rápida consolidación, para los Publishing Studies, ya sea en escuelas propias de edición o a través de escuelas de literatura, comunicación, periodismo, diseño, artes e informática, y en lo que resultará probablemente de la fusión de todas estas disciplinas: unas futuras facultades de Economía Cultural. ${ }^{37}$ El congreso académico By the Book, organizado desde 2014 por la Asociación Europea de Estudios Editoriales, aborda estos debates.

Comprender por qué y para qué lee la gente, qué usos prácticos hace de la lectura en su vida cotidiana, nos ayudaría a saber para qué y para quién editamos o diseñamos, cómo mira la sociedad a los editores, diseñadores, escritores, impresores y libreros, qué representan, cuál es su importancia y qué ven en ellos (si es que acaso los miran); entender desde afuera el propio campo editorial, su estructura, funcionamiento, las reglas que rigen la competencia entre los capitales económicos, simbólicos, sociales y culturales de los editores, y las formas en que luchan entre ellos por la legitimidad.

${ }^{37}$ Stevie Marsden, "Positioning Publishing Studies in the Creative and Cultural Economy", ponencia presentada en el Congreso de Estudios Editoriales By the Book 5, EuroPub, Florencia, Italia, 14 de junio de 2018. 
También está muy arraigada la creencia de que las reglas que gobiernan la lectura, la legibilidad, las artes de la edición y del diseño editorial, son universales y eternas, provienen de un orden superior, han existido siempre, no son socialmente construidas e impuestas, no surgieron en circunstancias históricas de tiempo y lugar, surgen de ciertos "lenguajes naturales", que subyacen a todas las culturas en todos los tiempos, y por tanto no son producto ni objeto de juegos de poder ni de luchas por la hegemonía dentro de los campos de la edición, diseño, cultura, arte, literatura o políticas educativas. En pocas palabras, que no pueden ni deben ser criticadas, discutidas o cambiadas.

Abrir estos debates mejoraría la relación entre editores, correctores, diseñadores, ilustradores, impresores y libreros, que defienden y cultivan con cariño sus propios imaginarios, su habitus y su illusio, sus propias leyendas de héroes y villanos, sus reglas y valores, la nobleza y la bondad intrínsecas del oficio de hacer libros, la obligación de preservar las tradiciones, la pureza del lenguaje, la eterna búsqueda de la perfección, la verdad y la belleza, el carácter irreemplazable del libro de papel, la libertad e inefabilidad del genio creativo, el uso de ejemplos positivos (Don Quijote, Cien años de soledad, Pedro Páramo) o negativos (Carlos Cuauhtémoc Sánchez, Paulo Coelho, El libro vaquero, cualquier texto de autoayuda y superación personal) o la presunta incompatibilidad del sucio dinero del mercado con la legitimidad del arte, la cultura, la ciencia y la tecnología.

Pese a que la cadena editorial podría estarse convirtiendo en rizoma, hélice, nube o enjambre, y las fronteras disciplinarias se van desdibujando, el habitus profesional de la edición, reproducido en las escuelas y muy especialmente en las editoriales, suele ser más bien conservador y se opone a poner en crisis estas nociones; acepta y favorece la imposición de reglas arbitrarias que dificultan negociar con las contradicciones: cada agente de la cadena piensa el todo desde el habitus y la illusio de su propio fragmento, sobrestima su propio habitus, cree que los problemas de su perfil profesional son la parte central del problema editorial y, sin percatarse, invisibiliza y subestima a los demás.

La máxima expresión es la violencia simbólica de la ocasional frase lapidaria: "jeso que tú haces no es editar!", "ieso que produces no es diseño!", "jeso que hacen los consumidores no es leer!", "ieso no es literatura!" o "ieso no es realmente un libro!".

El concepto de habitus es mucho más complejo que "el hábito" o "lo habitual", y es importante no confundirlos. Para Bourdieu, el habitus es un sistema de estructuras y reglas determinadas por las relaciones sociales y la inversión de tiempo, esfuerzo y dinero que hacen los individuos para ingresar, competir, ad- 
quirir, conservar y mejorar su posición en la estructura del campo (llegar a ser alguien); pero el habitus a su vez está predispuesto para ser estructurante porque determina sus creencias, sus acciones y sus decisiones. El habitus, con todo y esta definición (sí, es un aparente galimatías): una "estructura estructurada predispuesta a funcionar como una estructura estructurante", responde al viejo dilema de si el ser humano posee libre albedrío (al estilo idealista) o si está irremediablemente determinado por su lugar en la sociedad (al estilo materialista).

Los agentes que forman parte del campo editorial no son libres para hacer todo lo que quieran, pero sí pueden elegir lo que más les conviene entre varias prácticas posibles. No son totalmente libres porque sus creencias acerca de lo conveniente y lo correcto son producto de su educación. Son libres porque las estructuras del campo son estados temporales que cambian con el tiempo y cada quien usa como armas los capitales que le tocaron en suerte; pero no son demasiado libres porque están obligados a competir, negociar y hacer acuerdos con los demás agentes, y cualquier cosa que elijan traerá consecuencias. El habitus es un sistema de disposiciones duraderas y transferibles (es decir, que pueden enseñarse en la familia, la escuela o en el trabajo) que integran experiencias pasadas (de los individuos, en este caso, pero también de las instituciones, como han demostrado otros estudios) para decirnos cómo debemos actuar frente a ciertas situaciones, y es la matriz que estructura nuestras percepciones, apreciaciones, acciones y decisiones. ${ }^{38}$

El habitus está determinado por ciertas condiciones de existencia. Es un conjunto de principios que generan y organizan las prácticas y representaciones, adaptadas para que los sujetos luchen por conseguir un fin sin ser conscientes de la illusio que los hace elegir, aprender y realizar ciertas acciones que creen correctas. El habitus no es producto de la obediencia ciega ni de una organización deliberada y, sin embargo, hace que los individuos actúen de manera orquestada. ${ }^{39}$

El habitus es, al mismo tiempo, un "oficio", un capital de técnicas, referencias, conocimientos y habilidades, un conjunto de "creencias", comportamientos, leyendas, mitos, ritos y propiedades debidas a la historia de una disciplina y a su posición en la jerarquía de las diferentes disciplinas. Es, a la vez, la condición requerida para el funcionamiento del campo y el producto de este funcionamiento. ${ }^{40}$

\footnotetext{
${ }_{38}$ Pierre Bourdieu, Esquisse d'une théorie de la pratique (París: Droz, 1972), 178.

${ }_{39}$ Pierre Bourdieu, Le sens pratique (París: Minuit, 1980), 88-89.

${ }^{40}$ Bourdieu, "Algunas propiedades de los campos", 136.
} 
En el Diccionario Crítico de Ciencias Sociales, Enrique Martín Criado explica que cada sujeto piensa y actúa interiorizando las estructuras y relatos a partir de los cuales piensa y actúa el grupo social en el que ha sido educado. Esta interiorización crea en el individuo esquemas de percepción (división del mundo en categorías), apreciación (distinción entre lo bello y lo feo) y evaluación (distinción entre lo bueno y lo malo) desde los cuales se generarán sus "elecciones". Así, ni el sujeto es totalmente libre porque el habitus es el principio no elegido de todas sus elecciones (impuesto por quienes lo educaron) ni está totalmente determinado porque el habitus sólo es una predisposición que da cabida a muchos tipos de relaciones y a un abanico de prácticas posibles.

El habitus, como principio generador de prácticas sociales en sentido amplio, es adquirido inicialmente en la familia como parte de la "socialización primaria". De ahí parte el capital cultural de cada trabajador de la edición. El habitus que genera las prácticas específicas de un campo profesional se afina posteriormente en la escuela o en el trabajo, como parte de una "socialización secundaria"41 cuando se aprende el oficio. Este habitus es el que puede y debe ser reorientado mediante la profesionalización, a través de alguna clase de intervención pedagógica deliberada, que tradicionalmente se obtiene de un maestro o un jefe con mucho prestigio y experiencia, pero podría también adquirirse asistiendo a una escuela para editores. ${ }^{42}$

Ambas etapas de socialización implican familiarizarse con un conjunto de prácticas y aceptar como reales y correctas ciertas divisiones implícitas del mundo social; las prácticas pueden explicarse como la relación entre dos sistemas de relaciones, por un lado el históricamente construido que constituye el "campo" específico y, por otro, el que forma a los individuos como agentes de ese campo: éste es su habitus. ${ }^{43}$

Al dialogar con representantes de los diferentes eslabones de la cadena editorial se hizo visible que sus prácticas van perdiendo concordancia con los discursos de legitimación de sus respectivos perfiles profesionales. Eso podría señalar una grave crisis de identidad, escondida detrás de un discurso legitimador que históricamente ha sido muy potente porque se basa en el mito Guten-

\footnotetext{
${ }^{41}$ Berger y Luckmann, La construcción social, 164-174.

${ }^{42}$ Lev S. Vygotsky, El desarrollo de los procesos psicológicos superiores (Barcelona: Crítica, 1978), 123-140.

${ }^{43}$ Enrique Martín Criado, "Habitus", en Diccionario Crítico de Ciencias Sociales, ed. de Román Reyes (Madrid; México: Plaza y Valdés, 2009), acceso el 12 de febrero de 2020, http:// pendientedemigracion.ucm.es/info/eurotheo/diccionario/H/habitus.htm.
} 
berg, en la creencia en el poder civilizador de los libros, el laudes litterarum (el elogio de las letras) y la superioridad moral de los que leen, pero ha perdido mucho contenido y fuerza en las prácticas cotidianas.

En la industria editorial hay cierto consenso alrededor de que existe un núcleo conceptual, un corpus mínimo de cosas que todo editor, corrector o diseñador editorial debería saber, hacer y pensar, y que puede ser enseñado en una escuela, pero en la práctica las necesidades y los habitus específicos de los diferentes perfiles profesionales y sectores de la edición son muy variables.

Por ejemplo, un editor de literatura necesita conocimientos filológicos específicos para evaluar la calidad de un texto, pero para afirmar si merece o no ser publicado necesita, además, algún capital simbólico legitimado de modo que los autores y los críticos respeten su decisión. Sin embargo, la cadena de producción y los ciclos de reproducción del capital de un editor literario son relativamente predecibles, ya que en general sólo dependen de los tiempos de los premios de literatura y de las ferias del libro. Su problema es que la literatura se vende poco a poco, lector por lector, título por título.

Por su parte, un editor de libros de texto escolar requiere equipos de producción más complejos y costosos; asesores pedagógicos, científicos y técnicos, ilustradores, infografistas y diseñadores. Además, necesita una red de conexiones con un sólido capital social frente a los funcionarios que deciden las políticas educativas, desde el nivel nacional y estatal hasta cada escuela, cada aula y, a veces, también entre los padres de familia. Los tiempos son más apremiantes y los riesgos de la apuesta económica son mayores, pero la venta de los libros de texto es masiva, cíclica, tiene un público cautivo y se basa en el efecto multiplicador que genera la adopción.

Los primeros estudios sobre edición y lectura emanaron de la sociología de la literatura, ${ }^{44}$ por lo que los principales modelos teóricos y la propia metáfora de la cadena tienden a consagrar como canónicas las prácticas de la edición literaria de mediados del siglo XX. Aunque efectivamente existe un núcleo conceptual común a todas las prácticas que puede enseñarse en una escuela de estudios editoriales, los perfiles profesionales y actividades cotidianas varían con cada género, casa editorial, colección e incluso con cada título. Si bien hay similitudes que permiten emplear modelos abstractos -casi todos basados en la metáfora de la "cadena" o el "circuito" autor-lector-, el fenómeno editorial es

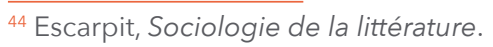


complejo y en la práctica no hay dos editoriales ni dos editores, ediciones, contenidos, libros, diseños, lectores o actos de lectura, iguales.

La realidad es que hay ediciones para la más amplia variedad de comportamientos de consumo cultural: narrativa canónica, popular, juvenil, drama clásico, contemporáneo o de vanguardia, lírica consagrada y experimental, obras clásicas o de masas; ediciones académicas de investigación, divulgación y difusión cultural; de ciencias exactas, naturales, de la salud, sociales, económicas, humanísticas en historia, filosofía, lingüística, psicología, derecho, arte, fotografía, ingeniería, mecánica, eléctrica, electrónica, computación, transporte, geografía, turismo, alimentos, cocina, política, religión, deportes, manuales técnicos, bricolaje, autoayuda y superación personal, cómic y novela gráfica; ediciones gubernamentales, universitarias o privadas; lucrativas, altruistas y predatorias; editoriales técnicas, libros de texto para la escuela, para la instrucción técnica o para los trabajadores; editoriales infantiles que hacen libros para bebés, libros pedagógicos, libros ilustrados y libros literarios. Y la lista sigue.

Cada uno de estos nichos tiene sutiles (o gruesas) diferencias con los demás nichos y, desde luego, con el modelo canónico general. Es distinto el perfil de sus lectores, el modelo de negocio, las prácticas discursivas, la forma de escribir, citar, seleccionar, contratar, corregir, diseñar, ilustrar, producir, promover, comercializar, leer y utilizar.

La mayoría de las personas que he entrevistado coincide en que hay un núcleo básico de cosas que todo editor debería saber, y que son susceptibles de enseñarse; pero al indagar sobre las prácticas concretas, en la realidad es cada modelo de edición el que determina lo que hace cada trabajador. Es usual analizar al sector editorial completo desde un solo modelo abstracto, pero cada entrevistado usa su propio modelo como referente del modelo general para legitimar su trabajo y, a veces, para subestimar o invisibilizar a quien opera dentro de modelos diferentes.

Si preguntamos a nuestros informantes cuáles son los problemas más graves que enfrenta el trabajo editorial, la respuesta de los gerentes tiende a situarlos en el terreno gerencial. Los correctores sitúan sus peores problemas profesionales como desacuerdos de norma lingüística. Los diseñadores los sitúan como problemas de diseño. Los educadores como problemas pedagógicos. Los bibliotecarios como problemas bibliotecológicos. Los libreros como problemas de librería..., y así sucesivamente. Éste es uno de los síntomas que revela la presencia de un problema complejo débilmente determinado o wicked problem: uno que se manifiesta en la interacción de muchos protagonistas di- 
ferentes, cada uno de ellos con experiencias, puntos de vista y marcos de referencia distintos e incluso opuestos. La complejidad de las interdependencias y contradicciones entre los propios agentes del problema impide que todos ellos vean, comprendan o acepten todas las posibles soluciones. Si un experto intenta resolverlo eligiendo a priori una de las diversas explicaciones que existen del mismo problema, privilegia la perspectiva de un grupo por encima de los otros, por lo cual puede quedarse atrapado en las luchas del campo y ni siquiera darse cuenta de qué es lo que realmente puede y debe resolver, o lo que no.

\section{Ni ciencia ni arte, sino todo lo contrario}

En 1973 Horst Rittel y Melvin Webber, ${ }^{45}$ retomados en 1995 por Richard Buchanan, ${ }^{46}$ propusieron el concepto de wicked problems, difícilmente traducible como problemas "perversos", "difíciles", "traviesos", "retorcidos", "embrollados", "tramposos", "indeterminados" o "débilmente determinados", para definir la dificultad de gestionar soluciones prácticas a problemas sociales complejos, a diferencia de la investigación de los tame problems (problemas "dóciles" o "mansos") de las ciencias exactas, e incluso a diferencia del estudio científico de los problemas sociales, porque no es lo mismo investigar un campo social para producir nuevo conocimiento, que entrar en él e investigarlo con la responsabilidad de solucionar problemas concretos.

Varias disciplinas abrieron este camino. En los dos últimos siglos ha sido recurrente la idea ilustrada de que los problemas sociales deben poder resolverse mediante algún tipo de planeación racional. La ciencia ha tenido éxito en resolver problemas físicos, químicos, biológicos y matemáticos, que ha logrado aplicar a través de las ingenierías; sin embargo, el holocausto nazi y el socialismo real reportan saldos trágicos en la aplicación de teorías "duras" a la solución "racional" de problemas sociales complejos.

El concepto de wicked problems surgió originalmente del trabajo social, donde la investigación participativa de los problemas sociales se vuelca más hacia la intervención que en casi cualquier otra disciplina; de ahí saltó a la gestión

\footnotetext{
${ }^{45}$ Horst Rittel y Melvin Webber, "Dilemmas in a General Theory of Planning", Policy Sciences 4 (1973): 155-169.

46 Richard Buchanan, "Wicked Problemas in Design Thinking", en The Idea of Design: A Design Issues Reader, ed. de Victor Margolin y Richard Buchanan (Cambridge, MA: MIT Press, 1995), 5-21.
} 
política, luego a la planificación del desarrollo y de ahí al diseño, ${ }^{47}$ no entendido como arte sino como factor de transformación social. La edición, la comunicación, el diseño y la administración de empresas son cuatro ejemplos de disciplinas que trabajan con problemas sociales concretos y necesitan investigarlos, pero no producen reglas universales como las ciencias exactas, por lo que tienden a ser indeterminadas (y wicked). Este tipo de problemas tiene las siguientes características:

- No pueden ser bien entendidos y problematizados hasta que no se hayan descartado las hipótesis de solución más obvias, por lo que usualmente se requieren soluciones creativas o inventivas.

- Los requisitos, reglas, limitaciones y recursos para resolverlos cambian con el tiempo.

- No pueden resolverse de forma científica y definitiva, sino sólo hasta cierto punto.

- No existe una sola solución posible ni un conjunto exhaustivo de soluciones potenciales.

- No vienen solos y suelen ser síntomas o consecuencias de otros mayores o más complejos.

- Son casuísticos, únicos, y sus soluciones no necesariamente generan reglas repetibles que sirvan para resolver otros casos análogos.

- Usualmente sólo pueden resolverse mediante esfuerzos colectivos, lo cual requiere negociar acuerdos, persuadir y conseguir que se produzcan cambios en el pensamiento y acción de muchas personas.

- Todas las posibles soluciones tienen consecuencias y pueden causar otros problemas.

- No hay stopping rules para saber cuándo detenerse o dejar de profundizar en ellos.

- Las posibles soluciones no son buenas o malas, verdaderas o falsas, sino sólo mejores, peores, suficiente o insuficientemente apropiadas.

- No existe demostración ni prueba definitiva de la validez de ninguna de las posibles soluciones, sino hasta cierto punto.

- El encargado de resolverlos no tiene un derecho inherente para hacerlo y suele ser un profesional externo, que conoce un tipo general indeterminado y abstracto de problemas semejantes al que se le presenta, pero suele estar distanciado de la situación pragmática real.

${ }^{47} \mathrm{lbid}$. 
- El encargado de resolver el problema tiene derecho a hacer un solo intento.

- Las escuelas no pueden enseñar un método para resolverlos más que de manera abstracta, en tanto permanecen indeterminados, y los alumnos sienten que no han aprendido nada mientras no tienen que enfrentar y resolver un problema determinado que se materializa en un caso concreto de la realidad.

- En cuanto el problema determinado se materializa en un caso concreto de la realidad, se vuelve diferente de todos los otros, de modo que lo aprendido, investigado y resuelto para ese caso no genera leyes generales y no necesariamente es aplicable a resolver otros casos análogos.

- Las escuelas no pueden enseñar, entonces, las reglas generales a la manera en que se hace en las ciencias, sino sólo aspirar a preparar al alumno de la mejor manera posible, desde la abstracción de lo alcanzable, para enfrentar la indeterminación y solventar la incertidumbre cuando lo abstracto se materialice de manera casuística.

Lo primero que hace un editor, idealmente, es un plan estratégico que revisa cada año o cada vez que ocurre algún cambio muy importante en el entorno. No todos los editores ponen en blanco y negro su planeación estratégica, pero les conviene al menos tener una visión de largo plazo, una misión y alguna vaga idea de los objetivos que distinguen su programa editorial de los demás: qué tipo de catálogo quieren construir, qué voz editorial pretenden proyectar, qué posición buscan ocupar en el universo de los textos, qué conversaciones desean suscitar, quién es su lector, qué tipo de contenidos desean ofrecer, qué márgenes de utilidad esperan (o aceptan), en qué franja de precios intentan competir, cómo planean reproducir su capital económico y simbólico. Es decir, cuál es su modelo editorial, que es a la vez modelo de uso, de mercado, de negocio y de diseño.

Es importante subrayar que este plan ya es un proceso de diseño (en el sentido más amplio del término). Claro, ya sabemos que en esta etapa el editor no utiliza un lápiz o una computadora para trazar la forma final de los objetos (que es como normalmente definimos al diseño en su sentido más pobre), pero este editor es un profesional que delibera sobre la forma y configuración de objetos aún inexistentes, pensados para resolver problemas y satisfacer necesidades.

Hay muchos modelos editoriales: muchos nichos de mercado, muchos modelos de negocio, muchos modelos de diseño y empresas de muchos tama- 
ños. Detrás de un sello editorial puede esconderse una persona que reproduce a solas su propio gusto literario en una laptop en la esquina de su comedor, en cualquier colonia clasemediera, o 600 asalariados sujetos a un programa industrial en un rascacielos de la Sexta Avenida en Manhattan. Esta diversidad de modelos es una de las cosas que más dificulta la investigación editorial. Tanto los editores como los académicos amamos los modelos generales, pero ningún modelo abstracto explica por sí mismo todos los casos.

Aunque a veces el editor sólo es quien decide, contrata o financia una edición, lo normal es que coordine toda la producción como un director de orquesta, y a veces realiza personalmente la mayoría de las tareas. Otras veces casi es una especie de coautor.

Cuenta una leyenda, difícil de documentar, que el editor lan Maire, de Leiden, no creyó rentable publicar por separado los ensayos de dióptrica, meteoros y geometría que le propuso René Descartes. Pensando cómo hacer un producto coherente con la suma de tres ensayos tan dispares, Maire encontró que el único hilo conductor entre los tres era que seguían el mismo método. Así pensó que prologarlos con un "discurso sobre el método" sí les daría cohesión e interesaría a los lectores, por lo cual obligó a Descartes a escribir un prólogo que, con los años, eclipsaría en fama a los tres ensayos originales.

Siempre existió el rumor de que la obra de Juan Rulfo fue extensivamente intervenida por Alí Chumacero y los editores del Fondo de Cultura Económica (FCE), lo cual parecería implicar que los textos canónicos de Rulfo no fueron "estrictamente" escritos por Rulfo. En 1995 el Fondo exhibió en la Feria Internacional del Libro de Guadalajara algunas pruebas de sus libros más famosos, donde era más que evidente dicha intervención. Sin embargo, tales intervenciones son habituales para cualquier autor; el trabajo de Chumacero no cuestiona el talento narrativo de Rulfo y sí, en cambio, incrementa su valor literario. Lo excepcional no es la intervención, sino que se haga visible, ya que lo normal es que el trabajo editorial no se documente por escrito, y eso les da mucho valor a las anécdotas. En nuestras entrevistas vimos la importancia que dan los editores y correctores a su propia invisibilidad que, junto con la competitividad económica y la exigencia de confidencialidad, se suma a las dificultades de la investigación editorial.

La historia de la edición francesa ${ }^{48}$ sólo pudo escribirse gracias a la magnífica organización y conservación de los archivos de las sociedades de tipógrafos francesas, pero con el estado en que se encuentra la mayoría de los archivos en

\footnotetext{
${ }^{48}$ Roger Chartier y Henri-Jean Martin, Histoire de l'édition française (París: Fayard, 1989).
} 
México eso será dificilísimo. Entre las contadas excepciones podemos mencionar trabajos como "Las casas editoriales del exilio español en México", de Lizbeth Zavala Mondragón, ${ }^{49}$ y Editar desde la izquierda: la agitada historia del Fondo de Cultura Económica y de Siglo XXI, de Gustavo Sorá. ${ }^{50}$ Asimismo, podemos esperar que al menos una parte de la sociología de la literatura mexicana avance con la publicación en app de los archivos del Fondo. ${ }^{51}$

Tampoco hay estadísticas suficientes y confiables. En México tenemos cifras, como las que publica el Estado, incluyendo los indicadores generados a partir de los registros de la Agencia Nacional del ISBN, y las que produce la Cámara Nacional de la Industria Editorial Mexicana (Caniem) sobre sus propios afiliados, pero estos datos son muy generales, suelen ser insuficientes y presentan diferentes problemas de confiabilidad, entre ellos que no todos los editores pertenecen a la Cámara, no todas las dependencias del Estado entregan sus datos oportunamente, no está claro a qué organismo corresponde la tarea de agregar los datos de la administración pública centralizada y descentralizada, y a nivel federal, estatal y municipal no todos los títulos se registran, no todas las empresas hacen pública toda su información por razones fiscales, de competitividad o de confidencialidad, y los datos son difíciles de comparar porque su metodología es distinta.

El resto de la información proviene de sondeos y existe una "zona gris" donde subsisten muchos editores que no podemos contar porque no están registrados en el Estado ni en la Cámara: editoriales independientes, artesanales, informales, algunos centros públicos de cultura estatales y municipales, escuelas, institutos y universidades, colectivos culturales, partidos políticos, iglesias y asociaciones religiosas, asociaciones civiles, organizaciones no gubernamentales y ediciones de autor. Una breve caminata por los pasillos de la Feria Internacional del Libro de Guadalajara permite suponer (y eso sólo a ojo de buen cubero) que los libros religiosos podrían representar entre 10 y $20 \%$ de la producción total del país, con pocos títulos y mucho tiraje; los universitarios otro tanto, pero a la inversa.

\footnotetext{
${ }^{49}$ Lizbeth Zavala Mondragón, "Las casas editoriales del exilio español en México", en Enciclopedia de la Literatura en México (4 de junio de 2019), acceso el 8 de febrero de 2020, http://www.elem.mx/estgrp/datos/1351.

${ }^{50}$ Gustavo Sorá, Editar desde la izquierda: la agitada historia del Fondo de Cultura Económica y de Siglo XXI (Buenos Aires: Siglo XXI, 2017).

${ }^{51}$ FCE, Archivo abierto. 80 años del Fondo de Cultura Económica (México: FCE, 2014), acceso el 12 de febrero de 2020, https://itunes.apple.com/mx/app/archivo-abierto.-80-anos$\mathrm{del} / \mathrm{id} 912009439 ? \mathrm{mt}=8$.
} 
En los diferentes modelos hay una constante: al editor le toca decidir qué contenidos se publican o no, así como contratar, supervisar y coordinar al resto de los agentes. En las entrevistas intentamos entender cómo se concibe y negocia la difícil dicotomía entre el control que debe ejercerse para coordinar a todos los colaboradores y la libertad creativa que requieren para dar lo mejor de ellos.

La corrección es obra del corrector, el diseño es del diseñador, las ilustraciones son del ilustrador, etcétera; todos estos son trabajos interpretativos basados en una lectura de lo que intenta decir el autor, pero vertido en un marco interpretativo y unas normas de estilo (editorial y gráfico) establecidas por el editor. Son trabajos por encargo que siguen el briefing, la estrategia y visión creativa del editor. Los artículos del 123 al 128 de la Ley Federal del Derecho de Autor otorgan a los editores la exclusividad sobre sus ediciones, incluyendo "las características tipográficas y de diagramación", ${ }^{2}$ al igual que el artículo 163 de la Ley Federal del Trabajo rige los derechos de los patrones sobre las invenciones realizadas por sus trabajadores. Históricamente la propiedad sobre las obras por encargo ha pertenecido a quien las encarga, como las primeras cursivas, talladas en 1499 por Francesco Griffo por orden y para beneficio de su jefe, Aldo Manuzio.

El diseño, estilo tipográfico, la diagramación e ilustraciones resultan de una interpretación del contenido hecha por el diseñador, tipógrafo o ilustrador, en una libertad acotada por la atención del editor a la pertinencia de su producto editorial. Si definimos "mal diseño" como una interpretación formal que genera desaprobación, conflictos y trabajo innecesario, un "mal diseñador" puede venir solo o acompañado de un mal brief y de un editor que no sabe qué necesita y espera del diseñador. O que no lo comunica.

En las entrevistas vimos que los editores "diseñan" para sí mismos cierta imagen mental del producto que planean, pero se enfrentan al problema de comunicarla de modo que el corrector, el diseñador, el ilustrador, el impresor y los demás profesionales la entiendan. Por eso un buen editor tendría que ser un buen crítico y comprador de estos servicios, capaz de imaginar y verbalizar qué quiere, qué necesita, qué se puede hacer o no, cuánto cuesta, cuánto tarda, cuándo lo están tratando de engañar.

De todo ello depende la calidad de la interpretación. Lo dicho para correctores, diseñadores o ilustradores es válido para todos los profesionales que

\footnotetext{
52 México, Ley Federal del Derecho de Autor (1996).
} 
interpretan y traducen las intenciones del editor, incluyendo a los administradores que organizan los materiales y los recursos; los abogados que procuran los derechos del editor y del autor; los preprensistas, impresores, encuadernadores y programadores digitales que se encargan del resultado material; los distribuidores, promotores, vendedores, libreros y voceadores que hacen llegar en tiempo y forma el producto a donde tiene que llegar, etcétera.

El editor tiene que comunicarse con todos los profesionales con quienes terceriza las labores que coordina y eso incluye ofrecer marcos interpretativos claros, para que todas las tareas traduzcan en forma razonable su intención original $y$, al final, sean percibidas por el lector como cierta unidad de sentido. Para lograr una edición de calidad, un buen editor necesita entender el sentido del contenido que edita, y luego lo suficiente de corrección, diseño, administración, derecho, ilustración, fotografía, tipografía, preprensa, impresión, encuadernación, programación digital, distribución, promoción, ventas, librerías, bibliotecas y mediaciones de lectura para saber qué pedir, cómo pedirlo y cómo pagarlo, esto es, reconocer el valor de lo que recibe; darse cuenta cuando un contenido, una interpretación, corrección, diseño, impresión, presupuesto, contrato, pedido o envío están mal hechos. "Unidad de sentido" implica que cada uno de los agentes, además de dar lo mejor que sabe hacer, haga interpretaciones coherentes y colaborativas, que se vayan sumando una a la otra para producir una sola experiencia total. Se insiste mucho en que el editor no tiene que hacer todo por sí mismo, pero usualmente, como vimos en las entrevistas, las partes del proceso que el editor ignora o desatiende son las que generan más conflictos y arrojan peores resultados.

Al no haber escuelas para editores o "libristas", como las hay para "periodistas", los distintos profesionales de la edición aprenden sus oficios en sitios distintos, con habitus, lógicas, éticas y estéticas distintas. Todos los entrevistados hablan desde la metáfora de la cadena, pero pocos la han visto completa y la mayoría todavía tiene uno o más eslabones que le son ajenos. Los profesionales de la edición recelan unos de otros, sobreestiman su propia aportación al conjunto, subestiman condescendientemente las aportaciones ajenas y disputan entre sí por la hegemonía sobre "lo editorial". Las entrevistas muestran que, cuando los gerentes hablan del "problema editorial" se refieren a problemas gerenciales; para los correctores, "lo editorial" son problemas de los textos y la norma lingüística; los diseñadores mencionan problemas de geometría o tipografía; para los impresores son problemas de las prensas y el papel, etcétera. 
Cuando un profesional defiende su hegemonía sobre el conjunto del campo, tiene que disminuir a los demás agentes: "un pequeño problema de corrección", "un pequeño problema de diseño" o "un pequeño problema de distribución" no es un legítimo problema editorial, "como los que yo resuelvo". El precio que se paga es una fragmentación agudísima, que deberían combatir prioritariamente los programas de profesionalización editorial. Cada agente de la cadena se ve como protagonista; cree que los demás son importantes, pero no tanto como él. Alguno admite que puede vivir sin conocer a los demás. Los que intervienen antes, "cadena arriba", mandan las cosas mal hechas. Los que siguen, "cadena abajo", no entienden la importancia y la dificultad del trabajo previo.

La fragmentación está tan normalizada que los mismos agentes de la cadena se oponen a romperla. El empresario editorial piensa que un buen editor sabe dirigir una empresa, el corrector es el que sabe corrección, el diseñador sabe diseñar y el impresor sabe imprimir. Nadie se conforma con que su parcela sea una pequeña parte de un todo. En el caso de los programas de enseñanza, capacitación o profesionalización, es normal exigir que se reduzca la enseñanza de "otras" tareas que parecen secundarias, subordinadas o fácilmente tercerizables.

Los entrevistados admiten que la fragmentación degrada la calidad de los productos y estresa el ambiente laboral, pero la consideran un "gaje del oficio": el conflicto no es grave, "la sangre nunca llega al río", siempre se logran acuerdos y "la chamba sale". Es un mal necesario al que hay que resignarse. Pero la queja vuelve a aparecer una y otra vez, como una sombra, a lo largo de las entrevistas: es más frecuente resolver la fragmentación con imposiciones y lucha por el poder que hacerlo negociando.

La formación de un editor profesional requeriría comprender todos los procesos, empezando por los menos tercerizables, que corresponden a su función directiva (planeación estratégica y decisión editorial), pero sin descartar una comprensión profunda de todos los demás habitus y lenguajes; sin llegar a la "todología", pero en grado suficiente para comunicarse fluidamente con todos los agentes, entender sus imaginarios, discursos, preocupaciones, saber qué se les puede pedir y en qué términos, responsabilizarse por lo que les pide, y tener tanta capacidad y autoridad para valorar y pagar lo justo por un trabajo bueno, así como para criticar con justicia uno malo. 


\section{¿Una teoría de la edición?}

En 2013 el editor británico Michael Bhaskar dijo abiertamente que es indispensable tener una teoría general de la edición para que esta industria logre sortear los cambios constantes en la tecnología y la economía cultural. Curiosamente, a pesar de ser un practitioner de tiempo completo que escribe y teoriza desde su experiencia, Bhaskar ha sido tildado de ser "demasiado teórico" y ha resultado difícil de digerir para los editores más tradicionalistas. Esto quizá se deba a que su modelo propone:

- Entender la edición como una actividad consistente en gestionar contenidos, y ya no en fabricar objetos (de papel o cualesquiera otros).

- Reemplazar el concepto de "publicación" por el de "amplificación".

- Reemplazar el concepto de "selección" por el de "filtrado".

- También requiere comprender dos conceptos abstractos, "marco" y "modelo".

El núcleo de mi argumentación elabora una teoría de la edición a partir de cuatro conceptos clave: marcos y modelos, filtrado y amplificación. Juntos constituyen la verdadera máquina de contenido. Parto de la premisa de que la edición nunca se separa del contenido. Dondequiera que se encuentre la edición, está el contenido. ${ }^{53}$

Bhaskar cuestiona la permanencia de la decisión de "publicar" como núcleo conceptual del trabajo editorial (publishing) ya que, como afirma Clay Shirky, a partir de Internet 2.0 publicar "ya no es un trabajo; es un botón: un botón que dice 'publicar' y, cuando lo oprimes, ya está". ${ }^{54}$ Nunca fue tan impreciso el acto de hacer público algo. Hay muchas formas de publicar, desde pegar fotocopias en los postes hasta "liberar" libros en los parques. Tenemos las redes sociales, donde el video de una botarga bailando alcanza fama viral a escala planetaria en 24 horas, sin la intervención de ningún editor y sin que su autor invierta ni un peso. Por otra parte, tenemos libros académicos deliciosamente editados, con atención a cada detalle ecdótico por expertos filólogos, pero que se almacenan en las bodegas, sin jamás hacerse del conocimiento público. Esto hace fundamental que repensemos qué significan las palabras clave del mundi-

${ }_{53}^{53}$ Bhaskar, La máquina de contenido, xxiv.

54 Ibid., xv. 
Ilo editorial, como señalamos, empezando por el verbo "publicar": en palabras de Raymond Williams, publicar es una "palabra clave", si bien "las palabras clave son problemáticas, pues ocultan contradicciones y significados alternativos". ${ }^{5}$

Bhaskar afirma que la edición está en crisis desde mucho antes de que la tecnología digital pusiera en duda si desaparecerá o tendrá sentido en el futuro, ${ }^{56}$ porque sus modelos de negocio, sus procesos de producción y la forma en que se piensa a sí misma como parte de la sociedad no evolucionaron a la velocidad necesaria. Para sustituir el verbo "publicar", Bhaskar propone lo que llama dos metáforas útiles: "el verdadero núcleo de la edición reside en el filtrado y la amplificación" ${ }^{\prime 57}$

El concepto de filtrado es la propuesta de Bhaskar para reemplazar el término selección, históricamente denostado porque, desde el siglo XVI, el poder del editor para decidir qué se publica y qué no fue considerado una forma injusta de censura, basada en el monopolio tecnológico y el interés económico, más que en el puro mérito literario. Este poder, como ha demostrado Roger Chartier, rebasó el ámbito económico y se convirtió en un derecho para inmortalizar: una patente de corso para decidir qué autores y qué textos llegarían a ser canónicos y formarían parte del patrimonio escrito de la humanidad, y qué autores y qué textos no. La revancha de los escritores parece ser que este superpoder de los editores ya no se sostenga: "publicar es oprimir un botón".

De hecho, con la tecnología actual el fenómeno se está invirtiendo: cualquiera puede publicar, pero no todos los contenidos tienen la misma calidad y credibilidad ni se adecúan a las expectativas de los lectores; una buena filtración se está convirtiendo en valor agregado para quien busca contenidos depurados, de calidad, con curaduría, garantías éticas y responsabilidad objetiva, acordes a modelos aceptados y respaldados por un capital simbólico. ${ }^{58}$ En la era de Internet 2.0 se están diferenciando los modelos de consumo: los usuarios celebran felices la libertad y la gratuidad (Wikipedia, Scribd, YouTube), pero con gusto pagan un premium por el control de calidad (Britannica, Kindle, Netflix). Como ocurre con las galletas, el capital simbólico de una editorial es el que le permite decir "donde ponemos este sello, ponemos contenidos muy buenos".

\footnotetext{
55 Ibid., 4.

${ }^{56}$ Ibid., ix, xix.

57 lbid., 24.

58 Ibid., 127.
} 
Bhaskar también propone el concepto de amplificación para distinguirlo de la simple publicación: una cosa es poner un contenido al alcance del público y otra es diseñar una estrategia deliberada para hacer que llegue a más personas:

Por amplificación me refiero a algo engañosamente sencillo, que va al corazón de toda intermediación cultural -noción de suyo nebulosa-: actuar de modo que se distribuyan o consuman más ejemplares de una obra o producto, o que se distribuyan y sean consumidas por personas que no lo harían sin el acto de intermediación. ${ }^{59}$

Aunque la propuesta de Bhaskar implica desplazar por completo el verbo publicar, el concepto de amplificación no es nuevo. Lucien Febvre y Henri-Jean Martin dicen: "no debe causar sorpresa que la aparición de la imprenta promoviera, como resultado inmediato, una mayor circulación de los libros que habían alcanzado el éxito [...] sumergiendo a otros en el olvido [...] la imprenta realizaba una obra de ampliación y selección".60

Desde Gutenberg, lo que hace una imprenta es sacar copias por encargo y su negocio es que las prensas trabajen el mayor tiempo posible, independientemente de los contenidos: "en general, los impresores no filtran ni seleccionan, tan sólo aceptan pedidos". ${ }^{61}$ Pero desde finales del siglo XV ha habido impresores que no esperan los pedidos y toman para sí mismos el riesgo de buscar, filtrar, copiar, amplificar y vender nuevos contenidos, apostando a colocarlos en los marcos, lugares, momentos, formatos y precios más adecuados con el propósito de satisfacer a un público que, para no apostar a ciegas, aprendieron a conceptualizar. ${ }^{62}$

Hasta la edición digital, el negocio de elegir a priori qué contenidos copiar o no obligaba a "no reproducir, salvo por error, un texto cuya venta no fuera segura". ${ }^{3}$ La editorial es un filtro que amplifica unos contenidos y eclipsa otros, según su posible demanda. Es decir, su acción es retórica. No sólo reproduce los discursos: los filtra, los amplifica, les da presencia, los inserta en un modelo socialmente aceptado que los hace pensables y visibles, colocándolos en el

\footnotetext{
59 Ibid., 137-138.

${ }^{60}$ Lucien Febvre y Henri-Jean Martin, La aparición del libro (México: FCE / Libraria, 2005), 290.

${ }^{61}$ Bhaskar, La máquina de contenido, 128.

${ }^{62}$ Febvre y Martin, La aparición del libro, 280.

${ }^{63}$ Ibid., 290.
} 
marco físico y social más adecuado para su recepción por un público posible, imaginable, construible.

\section{Retórica y semiótica de la edición}

La pragmática del proceso editorial, ya sea que lo llamemos cadena, circuito, rizoma, hélice, nube o enjambre, puede describirse con enorme flexibilidad y elegancia mediante la retórica; no se usa aquí la palabra retórica en el sentido peyorativo de "discurso vacío" ni en relación con el uso poético de figuras, sino aludiendo pragmáticamente "al contexto de uso del lenguaje, a la relación entre el emisor y el receptor, y al propósito que cada uno desea realizar a través del intercambio lingüístico". 64

Aunque no lo sepa, el editor actúa como un rétor que intenta poner cierto discurso con ciertos argumentos ante la atención de cierto público, para persuadirlo al menos de tres cosas: a) Que compre el producto editorial (reproduciendo el ciclo del capital económico), b) Que le reconozca algún valor literario, cultural, artístico y científico al contenido, para que lo lea y recomiende (reproduciendo el capital simbólico) y c) En algunos casos, que el propio contenido lo mueva hacia alguna acción concreta. Tradicionalmente la retórica se ha dividido (al igual que la edición) en una serie de distintos oficios, etapas o eslabones cuya secuencia no implica necesariamente una linealidad, sino la existencia de saberes diferentes que son integrados colaborativamente para construir una experiencia con unidad de sentido.

Al nivel del modelo general, hay una gran coincidencia entre los eslabones de la cadena editorial y los oficios de la retórica. La intellectio implica la indagación previa de la situación y del entorno, detección de las necesidades e investigación de los mercados; la inventio requiere tener un plan estratégico, tomar la decisión de qué se quiere decir y con qué argumentos va a decirse; la dispositio exige organizar y editar los contenidos para que las cosas sean dichas en el orden que las haga más convincentes; la elocutio implica un diseño que procure formas atractivas; la memoratio está mediada tecnológicamente por la imprenta y los medios digitales, que almacenan y a la vez reproducen el discurso en la forma de un producto de consumo, y la actio consiste en aplicar y evaluar; distribuir, comercializar, difundir, promover e investigar la recepción.

\footnotetext{
${ }^{64}$ Paula Carlino, Escribir, leery aprender en la universidad. Una introducción a la alfabetización académica (Buenos Aires: FCE, 2005), 25.
} 
Estas coincidencias en el modelo general se matizan, pero no desaparecen del todo al analizar caso por caso la diversidad de modelos editoriales, de negocio y de diseño. El carácter flexible de la retórica, más humanístico que científico, y su rico acervo histórico, permiten adaptar el modelo a muchos casos distintos. Conceptos como el de tópico, tanto el argumentativo cuasilógi$\mathrm{CO}^{65}$ como el literario, ${ }^{66}$ la euresis como alternativa al concepto de creatividad ${ }^{67} \mathrm{O}$ las metáforas conceptuales ${ }^{68}$ son aportaciones invaluables de las viejas y nuevas retóricas para comprender la complejidad de la edición y el diseño editorial.

De acuerdo con Adler y Van Doren ${ }^{69}$ es más fácil leer un libro teórico que uno práctico, porque un autor teórico sí es capaz de resolver por completo todos los problemas que se plantea, mientras que el autor práctico nunca termina si el lector no actúa. Eso pasa con la retórica. Al llegar a la actio, todos los manuales dicen: "lo que sigue es la acción. Vaya y actúe". Para una retórica completa se necesita tener oficio. Un rétor que domina la retórica pero no tiene técnica judicial no es un rétor judicial, porque carece de la actio; como un editor, diseñador o docente que domina la retórica pero carece de la técnica editorial, de diseño o didáctica para consumar la acción.

La retórica explica el proceso pragmático de la edición, pero éste, a su vez, está formado por muchas operaciones interpretativas puntuales de carácter intersemiótico: leer un texto (interpretarlo, pues toda lectura es una interpretación) permite seleccionarlo o no, por el lugar que creemos que ocupa o podría ocupar entre otros textos; traducirlo entre distintos idiomas; traducirlo en distintos dialectos, sociolectos e idiolectos más o menos "correctos" o "incorrectos" del mismo idioma; $y$, en varios momentos, traducirlo a otras semióticas no lingüísticas: imagen de portada, sistema tipográfico, estructura de página, objeto portador, epitextos, etcétera. Cada interpretación requiere conservar cierta unidad de sentido, pese al uso simultáneo de varios códigos distintos, lo cual hace muy importante que cada agente del proceso retórico se asuma como un operador semiótico y conozca sus propios problemas y riesgos interpretativos. ${ }^{70}$

${ }^{65}$ Chaïm Perelman y Lucie Olbrechts-Tyteca, Tratado de la argumentación (Madrid: Gredos, 1989).

${ }^{66}$ Ernst Curtius, Literatura europea y Edad Media latina (México: FCE, 2004).

${ }^{67}$ Richard McKeon, "La creatividad y el lugar común", Encuadre, Revista de la Enseñanza del Diseño Gráfico 2, núm. 7 (octubre de 2005): 28-39.

${ }^{68}$ George Lakoff y Mark Johnson, Metáforas de la vida cotidiana (Madrid: Cátedra, 1999).

${ }^{69}$ Mortimer Adler y Charles van Doren, Cómo leer un libro (Madrid: Debate, 2000).

${ }^{70}$ Gerardo Kloss Fernández del Castillo, "Ser editor: la retórica y la semiótica en la encrucijada de una profesión que se resiste a serlo", Mesa de Semiótica y Retórica, V Coloquio 
En 1959 el lingüista Roman Jakobson clasificó la traducción en tres tipos: interlingüística, intralingüística e intersemiótica, ${ }^{71}$ La interlingüística es la única que recibe propiamente el nombre de "traducción" y consiste en interpretar los signos verbales de un texto escrito en una lengua mediante signos verbales pertenecientes a otra lengua. Esta traducción permite que los lectores formados en una cultura conozcan textos escritos en el contexto de otras.

Pero hay otras formas de traducir que el mundo editorial no reconoce como tales. La traducción intralingüística consiste en interpretar los signos verbales de un texto escrito en una lengua mediante otros signos verbales pertenecientes a la misma lengua. Este tipo es parte de las capacidades cognitivas requeridas para comentar, resumir, sintetizar, condensar, comparar o criticar un texto, es decir del trabajo filológico, y la corrección de estilo o edición textual no es otra cosa que interpretar un texto y reformularlo, reemplazando partes de sus signos verbales en español por otros signos, también verbales y en español, pero que el corrector considera más correctos o apropiados para cierto tipo de norma culta. Un corrector "traduce" del español del autor a otro español un poquito más claro, más culto o más apegado a la norma de la editorial.

Por último, la traducción intersemiótica consiste en interpretar y reformular textos mediante signos pertenecientes a códigos no lingüísticos. Un caso intermedio y muy complejo es el de la tipografía, ese curioso híbrido que, por un lado, funciona como forma gráfica con un sistema relativamente abierto de metáforas y signos plásticos, y a la vez no deja de ser también escritura, un sistema de signos lingüísticos con funciones sintácticas y semánticas normadas.

Producir ilustraciones a partir de un texto implica trasladar al menos una parte del sentido desde un sistema lingüístico hacia uno de signos icónicos, simbólicos o plásticos. En un libro donde la imagen y el texto se van acompañando, existe la ventaja de que los lectores lo interpretan en relación con la imagen y la imagen en relación con el texto, por lo que la interpretación de ambos permanece relativamente controlada: como lo simplificaba Roland Barthes, el texto y la imagen se van "relevando" entre sí.

de la Asociación Mexicana de Estudios de Semiótica Visual y del Espacio (AMESVE), México, 2011.

${ }^{71}$ Roman Jakobson, "On Linguistic Aspects of Translation", en On Translation, Harvard Studies in Comparative Literature (Cambridge, MA: Harvard University Press, 1959), 233. 


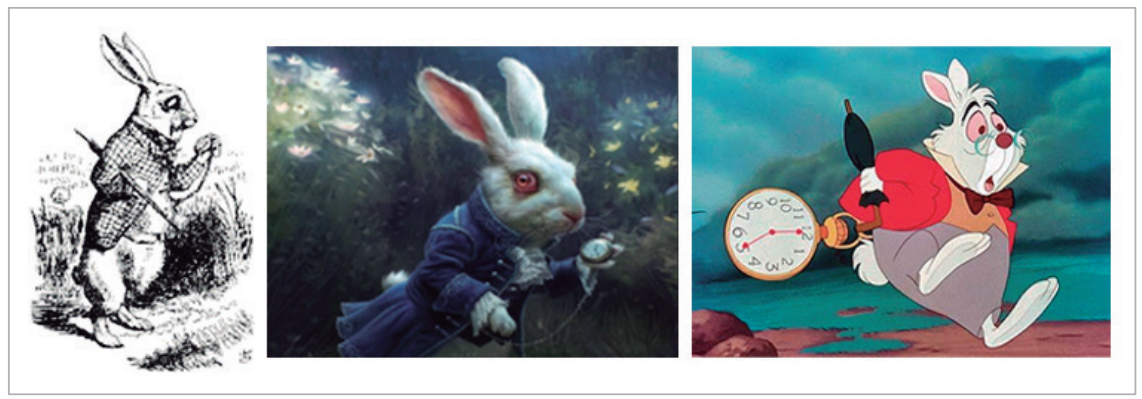

Tres lecturas de un mismo texto: "Pero cuando el conejo se sacó un reloj de bolsillo del chaleco, lo miró y echó a correr, Alicia se levantó de un salto, porque comprendió de golpe que ella nunca había visto un conejo con chaleco ni con reloj que sacarse de él y, ardiendo de curiosidad, se puso a correr tras el conejo por la pradera".

Pero "una imagen puede decir más de mil palabras" y, si no hay un texto para hacer el relevo, siempre queda abierto "anclar" cuál palabra de las mil posibles es la más plausible. ${ }^{72}$ Félix Beltrán reviraba: "también una palabra puede decir más que mil imágenes". Esta relación puede funcionar mediante relaciones plásticas, icónicas, indexicales o simbólicas; puede ser expresiva, referencial, persuasiva, poética, fática o metalingüística ${ }^{73}$ e interactuar Ilanamente o producir ironía, contrapunto, sinécdoque, etcétera. ${ }^{74}$

Pero nunca la interpretación es más abierta que al traducir un contenido en un sistema tan abstracto como la organización del espacio discursivo de la página o la presencia física, peso, color o textura de un objeto. El editor y diseñador interpretan el contenido y, de un modo u otro, deciden insertarlo en ciertos modelos y marcos, ${ }^{75}$ formas de organizar el espacio, concebir el objeto y utilizar los materiales que, al estar socialmente construidos y aceptados, implican un conjunto amplio pero finito de expectativas de sentidos y usos posibles.

Es impresionante ver cuántas ediciones distintas (cuántas interpretaciones filológicas, tipográficas, gráficas, objetuales, dentro de cuántos marcos distintos, para cuántos modelos editoriales distintos) se pueden hacer del mismo conte-

\footnotetext{
72 Roland Barthes, "Rhétorique de l'image", Communications. Recherches Sémiologiques 4 (1964): 41-42.

${ }^{73}$ Roman Jakobson, "Lingüística y poética", en Ensayos de lingüística general (Barcelona: Seix Barral, 1981), 347-360.

${ }^{74}$ Groupe $\mu$, Retórica general (Buenos Aires: Paidós, 1987).

${ }^{75}$ Bhaskar, La máquina de contenido, 98, 114-116.
} 
nido. Umberto Eco señala que "la práctica editorial nos enseña que es bastante fácil establecer si una traducción está equivocada y hay que corregirla". ${ }^{76}$ Eso debería ocurrir cuando un texto ha sido enmarcado en un diseño inapropiado, cuando el contenido no entra en el modelo editorial apropiado o el modelo de negocio no encaja con el modelo de uso. El mismo texto puede traducirse en varios libros diferentes siguiendo modelos editoriales distintos, que son diferentes modelos de negocio, de uso y de diseño, como varía el mismo Don Quijote según si aparece publicado en Porrúa, Cátedra, Alfaguara, Amazon, Ariel Juvenil, Planeta, Larousse o Teacher's Discovery.

Existen diversos enfoques teóricos para abordar la producción de los textos, la lectura, la mediación, la reproducción o los hábitos de consumo cultural: la lingüística, semiótica, teoría literaria, filología, retórica, sociolingüística, psicolingüística, pedagogía, historia y antropología se han ocupado de estos temas, pero sólo la historia cultural y la sociología de la literatura han dedicado esfuerzos explícitos para describir y explicar el funcionamiento concreto del campo editorial.

\section{La ciencia de lo escrito}

Por desgracia, no existe tal disciplina general dedicada a las ciencias del texto o de la comunicación escrita. Todas las ciencias usan el texto como herramienta de análisis, difusión, divulgación y reproducción de sus saberes, pero el texto propiamente dicho no se considera un objeto general de estudio, salvo en sus prácticas y usos específicos. Las escuelas de literatura invierten un gran esfuerzo en el estudio de los distintos géneros del texto literario, pero sin distraerse en el análisis de otros tipos de texto, y en las escuelas de periodismo se enseña la producción de textos, pero eminentemente periodísticos. Ambas disciplinas consideran el estudio de los textos como su patrimonio por antonomasia, y no es tan raro que haya literatos haciendo periodismo o periodistas haciendo literatura. La mayoría de las escuelas de comunicación se autodefinen por su deslinde respecto de las escuelas de periodismo, de modo que la comunicación escrita ocupa un lugar secundario en cuanto a la producción de textos para medios masivos como la radio o televisión. Sólo la lingüística es plenamente consciente de que su objeto de estudio es al mismo tiempo su herramienta, y su herramienta es su objeto de estudio.

${ }_{76}$ Umberto Eco, Decir casi lo mismo. Experiencias de traducción (México: Lumen, 2008), 21-26. 
El periodismo tiene una carrera específica cuya formación incluye algunos elementos de edición y diseño que, sin embargo, se siguen aprendiendo en la práctica, por ensayo y error. Abbott Liebling dedicó su libro The Wayward Pressman "a la creación de escuelas para editores, sin las cuales las escuelas de periodismo no tienen sentido". ${ }^{77}$ Sin embargo, la existencia de una figura profesional dedicada a hacer periódicos reduce significativamente las disputas por la legitimidad entre los periodistas.

No es lo mismo hablar de diseño, edición, futuro y crisis de los libros; o de las revistas, incluso en cuanto tienen en común con los libros. Es relevante la distinción entre libros y periódicos, por ejemplo su historia, periodicidad, ciclo de vida, mecanismos económicos, etcétera, y muy especialmente porque no existe la figura profesional de un "librista" (equiparable a la de un "periodista") ni las escuelas de "librismo" $y$, por tanto, las disputas por la legitimidad son mucho más frecuentes en el mundo de los libros.

El resto de las ciencias naturales, exactas y aplicadas tiene una relación mucho más extraña con sus prácticas de producción textual: la biología, las matemáticas o las ingenierías no sobrevivirían sin producir textos, pero invierten poco tiempo en el estudio sistemático de sus propias prácticas de lectura y escritura, como si pertenecieran al ámbito del sentido común. Un arquitecto una vez me dijo que él no necesitaba aprender a leer y escribir para la maestría, porque "eso ya lo había hecho en la primaria". Cuando estos profesionales advierten sus carencias, invitan a profesores de literatura, periodismo o lingüística para que den simples cursillos remediales, pero carece de sentido aprender en dos meses las convenciones textuales de la ingeniería, las matemáticas o la biología tomando clases con alguien que sólo sabe leer y escribir sobre literatura o periodismo.

Si existiera una ciencia general de la comunicación escrita, su sociología sería la encargada de estudiar el campo editorial y no la sociología de la literatura. Esto tendría ciertas ventajas. No estaríamos tan acostumbrados a considerar que el habitus de la edición literaria es el de todos los demás tipos de edición no literaria, ${ }^{78} \mathrm{O}$ a confundir la promoción de la lectura con la promoción de la literatura. Además, sería más lógico el tránsito de los distintos profesionales (médicos, abogados, biólogos, matemáticos, ingenieros) para convertirse en

\footnotetext{
${ }_{77}$ Abbott Joseph Liebling, The Wayward Pressman (Westport, CT: Greenwood Press, 1972).

${ }^{78}$ Irene Gunther y Leslie T. Sharpe, Manual de edición literaria y no literaria (México: FCE / Libraria, 2005).
} 
editores especializados de sus respectivos campos, identificando sus prácticas discursivas específicas y diseñando programas educativos apropiados.

Una de las causas por las que el fenómeno editorial no ha sido objeto de una disciplina con su propio campo académico parece ser su carácter transversal. Podríamos metaforizar la edición como un tren que, al viajar del autor al lector, se detiene en las estaciones disciplinarias como administración, crítica literaria, filología, lingüística, tipografía, fotografía, diseño, artes gráficas, encuadernación, programación digital, marketing, pedagogía o bibliotecología. El estudio separado de cada estación admite enfoques disciplinarios (cada estación es, en realidad, una disciplina), multi o interdisciplinarios, pero aprehender todo el fenómeno transversal completo (aprender a conducir los trenes) requiere lo que el Manifiesto de la Transdisciplinariedad Ilama "transgresión jubilosa de las fronteras entre las disciplinas".79

Esto supone el uso transversal de conceptos de varias disciplinas, principal pero no únicamente la retórica, semiótica, historia cultural y sociología. Para tratar de dar coherencia a estas frecuentes transgresiones, ya nos hemos visto obligados a desviarnos por aquí o por allá para sugerir conceptos básicos, o comentar posibles convergencias, comparaciones, paralelismos y divergencias entre estas disciplinas.

\section{Conclusiones}

La industria editorial está en una crisis y enfrenta debates tecnológicos, económicos, jurídicos, literarios, comerciales, sociales y culturales, no sólo estilísticos. Esto nos obligará, en perjuicio de la brevedad, a construir todo lo editorial como problema, entendiendo por agentes del campo editorial a quienes realizan las distintas prácticas de la edición y a ésta como un proceso de mediación entre un emisor, el autor (de textos, imágenes, partituras, mapas, videos, audio u otros contenidos susceptibles de considerarse obras) y un receptor colectivo e intere-

\footnotetext{
${ }^{79}$ Basarab Nicolescu et al., Manifiesto de la transdisciplinariedad (México: Multiversidad Edgar Morin, 2009), 11, acceso el 12 de febrero de 2020, https://www.google.com.mx/ search? source $=$ hp\&ei=JG9FXuBTg7i1BainmegL\&q=Basarab+Nicolescu+et+al. +Mani fiesto +de+la+transdisciplinariedad. $+\% 28$ Hermosillo\%3A+Multiversidad+Edgar+Mo rin\%2C+1996\%29\&oq=Basarab+Nicolescu+et+al.+Manifiesto+de+la+transdisciplinarie dad.+\%28Hermosillo\%3A+Multiversidad+Edgar+Morin\%2C+1996\%29\&gs_l=psy-ab.3. ..1730.6645..6974...0.0..0.0.0......6...2j1...gws-wiz.9HaJPG2Y8TQ\&ved=0ahUKEwjg9fzY$787 \mathrm{nAhUDXKOKHahTBr0Q4dUDCAU \& uact}=5$.
} 
sado en el contenido como satisfactor de una necesidad, los lectores, mediante una interfaz que (por ahora) denominamos libro.

Asumimos que si la comunicación entre el autor y los lectores pudiera ser directa, este proceso de mediación y esta industria no existirían, pero que entre el texto que entrega el autor y el libro que leen los lectores cabe una serie de transformaciones que producen valor agregado, hasta el punto en que el proceso puede ser un negocio viable.

La edición parece aspirar a un grado cero teórico donde ella misma no tendría razón de existir: la comunicación directa y sin intermediarios entre el autor y sus lectores. Si la edición existe es porque entre el autor y los lectores hacen falta varias mediaciones que fijan, reorganizan, filtran, reproducen y amplifican el contenido, permiten al autor llegar a más lectores y posibilitan que los lectores encuentren más contenidos de calidad.

Esas mediaciones, cuyo número y orden varían, constituyen un proceso no lineal y recursivo que, hasta donde hemos comprobado, involucra alguna forma de conocimiento previo, planeación estratégica, organización y filtraje de contenidos, diseño de formas, reproducción del soporte, distribución, comercialización, promoción, difusión y, algunas veces, evaluación. Aunque una parte de este proceso se llama "diseño", el diseñador sólo decide la forma visible del soporte, y todas las otras cosas que deben diseñarse en la edición, el proceso y el producto, no las diseña él, sino el editor.

Esto a su vez nos obligará a repensar los discursos alrededor de los numerosos términos clave que existen en este campo, aunque los más interesantes parecen ser lo que la gente hace (lectura), el objeto con que lo hace (libro), las características ideales del objeto (diseño) y el sistema alrededor del objeto, su producción y su consumo (edición). Hay otros dos términos fundamentales: texto, que varía radicalmente de un campo a otro, y digital, cuya fluidez también hace un poco ocioso tratar de definirlo unívocamente. Leer, libro, diseño y edición son términos clave, polisémicos y llenos de clichés. Por ejemplo, leer pueden ser muchos comportamientos diferentes de compra, uso, recepción, apropiación o interpretación de pinturas, fotos, partituras, mapas, videos o audiolibros, y no únicamente de textos. Asimismo, la palabra libro puede ser cualquier tipo de obra unitaria no periódica de cierta extensión, independientemente de que esté impresa en papel y encuadernada por el lomo, o no. Estos debates son justamente la razón que hace necesario dedicarle tiempo a discutir estos términos.

Pero la razón más urgente para emprender estos debates no es el cambio tecnológico. Más a fondo, los discursos idealizados acerca del campo editorial, 
que lo dibujan como una amable república de poetas y orgullosos trabajadores intelectuales, dificulta debatir acerca de la precariedad laboral y la explotación que sufren sus agentes, y que el cambio tecnológico tiende a agravar progresivamente.

\section{Esquema general de la "cadena" editorial y sus principales problemas}

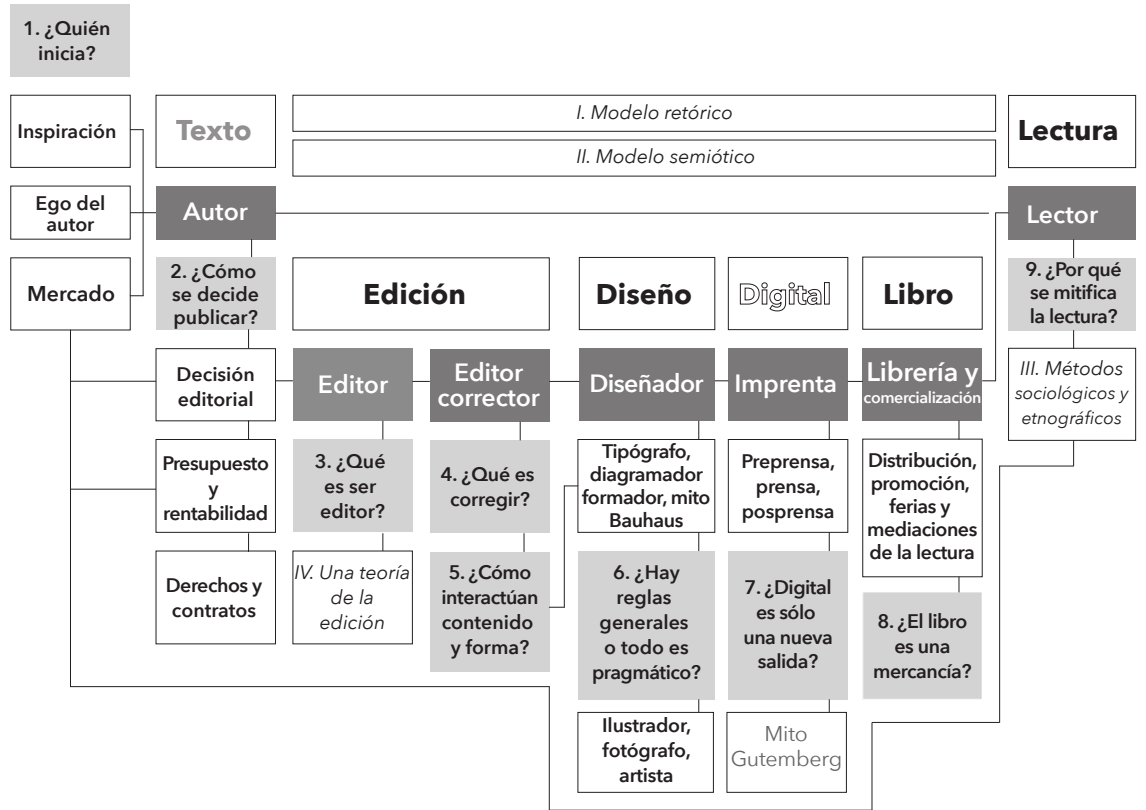

En este esquema aparecen, amén de seis términos clave (texto, edición, diseño, digital, libro y lectura), nueve preguntas y cuatro posibles rutas teóricas (en cursivas). 


\section{Referencias}

Adler, Mortimer y Charles van Doren. Cómo leer un libro. Madrid: Debate, 2000.

Álvarez Gayou, Juan Luis. Cómo hacer investigación cualitativa. Fundamentos y metodología. México: Paidós, 2009.

Aristóteles. Poética. Madrid: Gredos, 1974.

Barthes, Roland. "Rhétorique de l'image". Communications. Recherches Sémiologiques 4 (1964): 41-42.

Barvo, Carmen. Manual de edición. Bogotá: Centro Regional para el Fomento del Libro en América Latina y el Caribe, 1996.

Baverstock, Allison. Are Books Different? Marketing in the Book Trade. Londres: Kogan Page / BHTC, 1993.

Berger, Peter y Thomas Luckmann. La construcción social de la realidad. Buenos Aires: Amorrortu, 2003.

Bhaskar, Michael. La máquina de contenido. Hacia una teoría de la edición desde la imprenta hasta la red digital. México: Fondo de Cultura Económica, 2014.

Bourdieu, Pierre. "Algunas propiedades de los campos". En Sociología y cultura, 135-141. México: Consejo Nacional para la Cultura y las Artes, 1990.

Bourdieu, Pierre. Esquisse d'une théorie de la pratique. París: Droz, 1972.

Bourdieu, Pierre. "Una revolución conservadora en la edición". En Intelectuales, política y poder, 223-267. Buenos Aires: Eudeba, 2000.

Bourdieu, Pierre. Le sens pratique. París: Minuit, 1980.

Bourdieu, Pierre. "Los tres estados del capital cultural". En Las estrategias de la reproducción social, 213-220. Buenos Aires: Siglo XXI, 2011.

Bourdieu, Pierre y Roger Chartier. "La lectura, una práctica cultural". En El sentido social del gusto, 253. México: Siglo XXI, 2010.

Buchanan, Richard. "Wicked Problems in Design Thinking". En The Idea of Design: A Design Issues Reader. Edición de Victor Margolin y Richard Buchanan, 5-21. Cambridge, MA: Massachusetts Institute of Technology Press, 1995.

Carlino, Paula. Escribir, leer y aprender en la universidad. Una introducción a la alfabetización académica. Buenos Aires: Fondo de Cultura Económica, 2005.

Cervantes Becerril, Freja I. "Colecciones y formación de gustos literarios en México". Andamios: Revista de Investigacion Social 6, núm. 12 (diciembre de 2009). 
Chartier, Roger. "Gutenberg fue precursor del fordismo: Chartier". Babelia, El País Digital (7 de mayo de 2019). Acceso el 12 de febrero de 2020. https:// elpais.com/cultura/2019/05/07/babelia/1557222755_157917.html?id_ externo_rsoc=TW_CC.

Chartier, Roger y Henri-Jean Martin. Histoire de l'édition française. París: Fayard, 1989.

Chartier, Roger y Carlos A. Scolari. Cultura escrita y textos en red. Barcelona: Gedisa, 2019.

Crovi Druetta, Delia et al. Industrias culturales en México: reflexiones para actualizar el debate. México: Tintable, 2013.

Cruz Quintana, Fernando. "Desarrollo histórico estructural de la industria librera mexicana en la era digital". Tesis de doctorado, Universidad Nacional Autónoma de México, 2017.

Curtius, Ernst. Literatura europea y Edad Media latina. México: Fondo de Cultura Económica, 2004.

Darnton, Robert. "Reading, Writing, and Publishing in Eighteenth Century. France: A Case Study in the Sociology of Literature". Daedalus 100(1) (1971): 214-256.

Darnton, Robert. "What is the History of Books?". Daedalus 111(3) (1982): 65-83.

Davies, Gill. Book Commissioning and Acquisition. Londres: Blueprint, 1995.

Eco, Umberto. Decir casi lo mismo. Experiencias de traducción. México: Lumen, 2008.

Escarpit, Robert. Sociologie de la littérature. París: Presses Universitaires de France, 1958.

Febvre, Lucien y Henri-Jean Martin. La aparición del libro. México: Fondo de Cultura Económica / Libraria, 2005.

Fondo de Cultura Económica. Archivo abierto. 80 años del Fondo de Cultura Económica. México: Fondo de Cultura Económica, 2014. Acceso el 12 de febrero de 2020. https://itunes.apple.com/mx/app/archivo-abierto.-80anos-del/id912009439? mt=8.

Groupe $\mu$. Retórica general. Buenos Aires: Paidós, 1987.

Groupe $\mu$. Tratado del signo visual. Para una retórica de la imagen. Madrid: Cátedra, 1996.

Gunther, Irene y Leslie T. Sharpe. Manual de edición literaria y no literaria. México: Fondo de Cultura Económica / Libraria, 2005.

Huxley, Aldous. Brave New World. Londres: Chatto \& Windus, 1932.

Jackson, Holbrook. The Reading of Books. Nueva York: Scribner's, 1947. 
Jakobson, Roman. "On Linguistic Aspects of Translation". En On Translation. Harvard Studies in Comparative Literature, 232-239. Cambridge, MA: Harvard University Press, 1959).

Jakobson, Roman. "Lingüística y poética". En Ensayos de lingüística general, 347-360. Barcelona: Seix Barral, 1981.

Kloss Fernández del Castillo, Gerardo. "Discursos, imaginarios y conflictos en la inserción del diseño en el campo de la edición". Tesis de doctorado, Universidad Autónoma del Estado de Morelos, 2016.

Kloss Fernández del Castillo, Gerardo. "Ser editor: la retórica y la semiótica en la encrucijada de una profesión que se resiste a serlo". Mesa de Semiótica y Retórica, V Coloquio de la Asociación Mexicana de Estudios de Semiótica Visual y del Espacio (AMESVE). México, 2011.

Lakoff, George y Mark Johnson. Metáforas de la vida cotidiana. Madrid: Cátedra, 1999.

Liebling, Abbott Joseph. The Wayward Pressman. Westport, CT: Greenwood Press, 1972.

Marsden, Stevie. "Positioning Publishing Studies in the Creative and Cultural Economy". Ponencia presentada en el Congreso de Estudios Editoriales By the Book 5, EuroPub, Florencia, Italia, 14 de junio de 2018.

Martín Criado, Enrique. "Habitus". En Diccionario Crítico de Ciencias Sociales. Edición de Román Reyes. Madrid; México: Plaza y Valdés, 2009. Acceso el 12 de febrero de 2020. http://pendientedemigracion.ucm.es/info/euro theo/diccionario/H/habitus.htm.

McKeon, Richard. "La creatividad y el lugar común". Encuadre, Revista de la Enseñanza del Diseño Gráfico 2, núm. 7 (octubre de 2005): 28-39.

México. Ley Federal del Derecho de Autor, 1996.

Nicolescu, Basarab et al. Manifiesto de la transdisciplinariedad. México: Multiversidad EdgarMorin,2009. Accesoel 12 defebrero de2020.https://www.google.

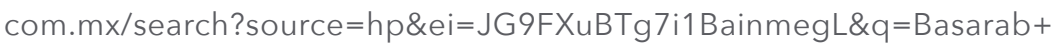
$\mathrm{Nicolescu+et+al.+Manifiesto+de+la+transdisciplinariedad.+ \% 28Hermo}$ sillo\%3A+Multiversidad+Edgar+Morin\%2C+1996\%29\&oq=Basarab+ Nicolescu+et+al.+Manifiesto+de+la+transdisciplinariedad.+\%28Hermosi Ilo\%3A+Multiversidad+Edgar+Morin\%2C+1996\%29\&gs_I=psy-ab.3 $\ldots 1730.6645 . .6974 \ldots 0.0 .0 .0 .0 \ldots \ldots .6 \ldots .2 j 1 . . g w s-w i z .9 H a J P G 2 Y 8 T Q \& v e$ $\mathrm{d}=$ 0ahUKEwjg9fzY787nAhUDXK0KHahTBrOQ4dUDCAU\&uact=5.

Orwell, George. Nineteen Eighty-Four. Londres: Secker and Warburg, 1949. 
Perelman, Chaïm y Lucie Olbrechts-Tyteca. Tratado de la argumentación. Madrid: Gredos, 1989.

Pimentel, Manuel. Manual del editor. Córdoba: Berenice, 2007.

Rittel, Horst y Melvin Webber. "Dilemmas in a General Theory of Planning". Policy Sciences 4 (1973): 155-169.

Schatzkin, Leonard. Cómo seleccionar títulos rentables. Herramientas estadísticas para la venta de libros. México: Fondo de Cultura Económica, 2005.

Sorá, Gustavo. Editar desde la izquierda: la agitada historia del Fondo de Cultura Económica y de Siglo XXI. Buenos Aires: Siglo XXI, 2017.

Therborn, Göran. ¿Cómo domina la clase dominante? Madrid: Siglo XXI España, 1979.

UNESCO. Manual de administración editorial. Bogotá; Madrid: Book House Training Centre / Centro Regional para el Fomento del Libro en América Latina y el Caribe, 1992.

UNESCO. Profession: éditeur. Montreal: HMH Hurtubise, 1993.

Vygotsky, Lev S. El desarrollo de los procesos psicológicos superiores. Barcelona: Crítica, 1978.

Williams, Raymond. Palabras clave. Un vocabulario de la cultura y la sociedad. Buenos Aires: Nueva Visión, 2003.

Wittgenstein, Ludwig. Tractatus logico-philosophicus. Barcelona: Alianza, 1981.

Worsøe-Schmidt, Lisbeth. "New Players in the Danish Book World. Challenges for the Sociology of Litterature". Ponencia presentada en el Congreso de Estudios Editoriales By the Book 5, EuroPub, Florencia, Italia, 15 de junio de 2018.

Worsøe-Schmidt, Lisbeth y Johan Svedjedal. The Literary Web: Literature and Publishing in the Age of Digital Production. Estocolmo: Kungliga Biblioteket, 2000.

Zaid, Gabriel. "Por una ley del libro". En Crítica del mundo cultural. México: El Colegio Nacional, 1999.

Zavala, Lauro. Laberintos de la palabra impresa. México: Universidad Autónoma Metropolitana, Unidad Xochimilco, 1994.

Zavala, Roberto. El libro y sus orillas. Tipografía, originales, redacción, corrección de estilo y de pruebas. México: Fondo de Cultura Económica, 2012.

Zavala Mondragón, Lizbeth. "Las casas editoriales del exilio español en México". En Enciclopedia de la Literatura en México (4 de junio de 2019). Acceso el 8 de febrero de 2020. http://www.elem.mx/estgrp/datos/1351.. bg 